\title{
Assessment of Microbiological Indoor Air Quality in Cattle Breeding Farms
}

\author{
Justyna Szulc $^{1^{*}}$ Małgorzata Okrasa $^{2}$, Katarzyna Dybka-Stępień ${ }^{3}$, Michael Sulyok ${ }^{4}$, \\ Adriana Nowak ${ }^{1}$, Anna Otlewska ${ }^{3}$, Bogumila Szponar ${ }^{5}$, Katarzyna Majchrzycka ${ }^{2}$
}

\author{
${ }^{1}$ Department of Environmental Biotechnology, Lodz University of Technology, tódź 90-924, Poland \\ ${ }^{2}$ Department of Personal Protective Equipment, Central Institute for Labour Protection—National Research Institute, \\ Łódź 90-133, Poland \\ ${ }^{3}$ Institute of Fermentation Technology and Microbiology, Lodz University of Technology, Łódź 90-924, Poland \\ ${ }^{4}$ Center for Analytical Chemistry, Department of Agrobiotechnology University of Natural Resources and Life Sciences, \\ Tulln A-3430, Austria \\ ${ }^{5}$ Institute of Immunology and Experimental Therapy, Polish Academy of Sciences, Wroctaw 53-113, Poland
}

\begin{abstract}
This study, which was conducted on a farm in central Poland from February till April 2019, aimed to evaluate microbiological threats on cattle breeding premises by counting and identifying the microorganisms (via culturing and highthroughput sequencing), assessing the endotoxin concentrations (via gas chromatography-mass spectrometry [GC-MS]) and analysing the secondary metabolites (including mycotoxins) in the air and sedimented dust (via liquid chromatographytandem mass spectrometry [LC-MS/MS]) in six barns. In addition, the cytotoxicity of the dust to the human epithelial lung cell line was determined by using the MTT [3-(4,5-dimethylthiazol-2-yl)-2,5-diphenyltetrazolium bromide] assay. The concentrations of the total dust in the barns ranged from 0.175 to $0.351 \mathrm{mg} \mathrm{m}^{-3}$, with the dominant fraction $(67.4-96.4 \%)$ displaying an aerodynamic diameter of $<1 \mu \mathrm{m}$. The bacterial and fungal concentrations fell between $7.14 \times 10^{3}$ and $3.88 \times$ $10^{4} \mathrm{CFU} \mathrm{m} \mathrm{m}^{-3}$, and $5.53 \times 10^{1}$ and $1.30 \times 10^{4} \mathrm{CFU} \mathrm{m}^{-3}$, respectively. The microbial population measured in the air and that in the settled dust exhibited a linear relationship, with an $\mathrm{R}^{2}$ of $0.8349-0.9471$. We detected 172 and 210 bacterial/archaeal genera and 89 and 43 fungal genera in the dust and in the air, respectively. The dust samples were found to contain endotoxin concentrations of 98.98-178.31 nmol LPS mg ${ }^{-1}$ and a cytotoxicity of 5.66-13.99 $\mathrm{mg} \mathrm{mL}^{-1}$. High-throughput sequencing revealed extensive biodiversity in the microorganisms, which hitherto has not been reported for cattle farms. Of the identified species, those belonging to the genera Bacteroides, Corynebacterium, Staphylococcus, Ruminococcus, Aspergillus and Cladosporium potentially affect human and cattle health. Furthermore, the dust contained 113 chemical compounds, including characteristically fungal metabolites, bacterial metabolites, phytoestrogens and antibiotics. Future research should focus on the epidemiology of farmer exposure to the harmful biological agents discovered in this study.
\end{abstract}

Keywords: Cattle breeding; Bioaerosol; Metagenomic analysis; Mycotoxins; Cytotoxicity.

\section{INTRODUCTION}

People working in professions such as farming, including cattle farming for milk and meat, are particularly susceptible to contact with harmful biological agents (Directive 2000/54/EC; Dutkiewicz et al., 2011; Corrao et al., 2012). These include allergenic and/or toxic agents, and those causing zoonoses and other infectious diseases (Rim and Lim, 2014). The former constitute biological particles (viruses, bacteria, endotoxin, fungi, secondary metabolites of moulds, and others), which

\footnotetext{
${ }^{*}$ Corresponding author.

Tel.: +48-426313470; Fax: +48-426313274

E-mail address: justyna.szulc@p.lodz.pl
}

together with organic dust and water droplets are suspended in the air and form bioaerosol (Lawniczek-Wałczyk and Górny, 2010; Rim and Lim, 2014). The main source of harmful biological agents in cattle breeding premises are substances of animal origin (e.g., secretions, excrements, feather fragments or exfoliated epidermis) and vegetal matter used as feed or bedding. At least $40 \%$ of organic dust particles present in the bioaerosol have a diameter of $4 \mu \mathrm{m}$ or less. At this size, they are capable of reaching the alveoli via the trachea and bronchi, and can have allergic or toxic effects (Hameed and Khodr, 2001; Lee et al., 2006). The size of particles suspended in the air is one of the factors that determines how deep they can penetrate into the human respiratory system. Size also plays a role in retention time within the body, which affects the level of toxicity to humans. For this reason, division into size classes (fractions) is the most commonly used criterion 
for determining the highest allowable concentration of these particles at workplaces. In Europe, there are two types of occupational exposure limits (OELs): (i) EU limits set by the European Agency for Safety and Health at Work and (ii) national exposure limits set individually by the member states. However, EU and national OELs may differ from the limits set in non-European countries. For example, 8 -h exposure limits can range from $4 \mathrm{mg} \mathrm{m}^{-3}$ (Germany, insoluble solid particles) to $15 \mathrm{mg} \mathrm{m}^{-3}$ (USA [OSHA]). For respirable dust, the 8-h exposure limits range from $1.25 \mathrm{mg} \mathrm{m}^{-3}$ (Germany, insoluble solid particles) to $6 \mathrm{mg} \mathrm{m}^{-3}$ (Hungary). OELs may also vary significantly depending on the particular type of dust. For instance, for organic grain dust the exposure limits range from $1 \mathrm{mg} \mathrm{m}^{-3}$ (Japan [JSOH]) to $10 \mathrm{mg} \mathrm{m}^{-3}$ (Ireland, USA [OSHA] and Great Britain; GESTIS, 2018).

The number of microorganisms in the air of cattle breeding farm premises amounts to $4.4 \times 10^{4}-1.5 \times 10^{7} \mathrm{CFU} \mathrm{m}^{-3}$ (Larsson et al., 1988; Dutkiewicz et al., 1994; Seedorf et al., 1998).

Many species of bacteria can pose a health risk to people professionally involved in cattle farming. Among them the genus $S$. suis should be mentioned as an etiological factor of zoonotic meningitis, arthritis, pneumonia, endocarditis and deafness (Bartelink and van Kregten, 1995). In turn, Campylobacter sp. bacteria can cause campylobacteriosis in farmers resulting in enteritis and gastritis (Rim and Lim, 2014). Moreover, Acinetobacter calcoaceticus, Alcaligenes faecalis, Pasteurella aerogenes, Pantoea agglomerans and Rahnella are also responsible for farmers' infections (Ejlertsen et al., 1996; Milanowski et al., 1998). In addition, some of them (A. faecalis and P. agglomerans as well as Arthrobacter globiformis and Agromyces ramosus rods) are a source of highly biologically active allergens that may cause extrinsic allergic alveolitis (EAA), also known as hypersensitivity pneumonitis. Moreover, there are indications that $P$. agglomerans may induce occupational dermatitis. Non-tuberculosis bacilli from the genus Mycobacterium, present in dust, soil particles and animal products (meat, milk), are also dangerous for workers involved in cattle breeding. They may cause lung infection or lymph node inflammation in immunocompromised subjects (Rim and Lim, 2014).

Due to the presence of gram-negative bacteria in cattle breeding premises, there is also the presence of endotoxins in the bioaerosol. Endotoxins, together with respirable dust, enter the lungs and non-specifically activate lung macrophages, causing inflammation, fever, gas exchange disorders and bronchospasms. They also play an important role in the pathogenesis of organic dust toxic syndrome (ODTS) and may aggravate asthmatic reactions (Rylander and Peterson, 1994; Rylander, 2002).

Bioaerosol in cattle breeding rooms also contains actinomycetes. They are the etiological factor behind "farmer's lung", a well-known EAA. The most allergenic species include Saccharopolyspora rectivirgula, S. viridis, Thermoactinomyces vulgaris and $T$. thalpophilus that proliferate in moist, self-heating vegetal matter (grain, feed, hay and silage). Actinobacteria are an etiological factor in opportunistic infections in immunocompromised subjects or people with immune system dysfunction. This group comprises invasive pathogens from the genera Actinomyces, Corynebacterium, Gordonia, Mycobacterium, Nocardia and Tsukamurella and opportunistic pathogens-Rothia, Nocardiopsis and Propionibacterium - characterised by a special tendency to attack the lungs and the brain (Lacey and Crook, 1988; Schaal and Lee, 1992).

Likewise, moulds can also be present in cattle farms, which may be etiological factors for allergic or immunotoxic diseases. Moulds from the genera Alternaria, Aspergillus, Penicillium, as well as Cladosporium, Fusarium, Mucor and Scopulariopsis are most often isolated from the air in cattle breeding premises. Candida, Rhodotorula and Cryptococcus are the most common yeasts found in this environment. Workers, who are exposed to them, may suffer from allergic rhinitis, bronchial asthma, ODTS or skin mycoses (Sahin et al., 2005; Dave et al., 2015).

Many mould species (mainly from genera Alternaria, Aspergillus, Fusarium, Penicillium, and Stachybotrys) produce mycotoxins, of which aflatoxins, ochratoxin A, trichothecenes, satratoxin and zearalenone have the greatest clinical significance (Bennett and Klich, 2003). Mycotoxins are usually present in the air as components of spores or fragments of hyphae of moulds. Also these metabolites can be secreted directly into the air by toxigenic moulds. It was shown that mycotoxin inhalation may have up to ten times more of a toxic effect than dermal, gastrointestinal or intraperitoneal exposure. This fact may be due to greater bioavailability of mycotoxins or the ease with which they can penetrate the capillary walls in the alveoli (Soroka et al., 2008).

The problem of exposure of cattle breeding farm workers to biological agents is all the more important considering that amongst the most consumed meats in the world, beef comes in at third place after pork and poultry. In 2017, the cattle population amounted to 984.53 million heads, and the main cattle producers included India, Brazil, China, United States of America and European Union countries (Food and Agriculture Organization of the United Nations, 2012). In Poland as well, cattle farming is an important branch of agriculture, and its population in 2017 equalled 6.04 million heads. Therefore, there is a real need for detailed identification of microbiological threats in such facilities, considering that the research is limited (Dungan et al., 2010; Lecours et al., 2012). Therefore, the aim of the study was to evaluate the microbiological threats in cattle farms, which comprised assessing the number and types of microorganisms, and determining the concentrations of bacterial endotoxins and secondary mould metabolites (including mycotoxins) in the air and sedimented dust. High-throughput sequencing on the Illumina platform was used for the first time for the identification of harmful biological agents in this workplace. In addition, the cytotoxicity of sedimented dust against a human epithelial lung cell line was determined, and the premises studied were characterised in terms of microclimatic conditions and airborne dust concentration.

\section{METHODS}

\section{Cattle Farm Studied}

The study was performed at a farm that rears cattle for 
dairy and beef. The majority of cattle at the farm were of the Holstein-Friesian breed with a black and white coat. The animals were reared in the barn system. The farm is located in central Poland (Lodz Voivodeship). The study was undertaken between February and April 2019 in six barns, which are described in Table 1.

Temperature, relative humidity and airflow rate were measured using a thermo-anemometer (VelociCalc $\AA$ MultiFunction Velocity Meter 9545; TSI Inc., USA).

\section{Airborne Dust Concentration Measurement}

Airborne dust concentration was measured using a portable laser photometer (DustTrak ${ }^{\mathrm{TM}}$ DRX Aerosol Monitor 8533; TSI Inc., USA). The device simultaneously measured sizesegregated mass concentrations of particulate matter (PM) corresponding to $\mathrm{PM}_{1}$ (particles and droplets with diameters $<1 \mu \mathrm{m}), \mathrm{PM}_{2.5}(<2.5 \mu \mathrm{m}), \mathrm{PM}_{4}(<4 \mu \mathrm{m}), \mathrm{PM}_{10}(<10 \mu \mathrm{m})$ and total PM (all particles from the measured diameter size range) size fractions. The detection range of the instrument was between 0.001 and $150 \mathrm{mg} \mathrm{m}^{-3}$ for particles from 0.1 to $15 \mu \mathrm{m}$ in size. Prior to each experiment, zero calibration was performed. The measurements were obtained at a height of $1.5 \mathrm{~m}$ from ground level in triplicates for each location, with a sampling rate of $3 \mathrm{~L} \mathrm{~min}^{-1}$ and a sampling interval of $5 \mathrm{~s}$.

\section{Microbial Contamination Analysis}

Microorganism numbers were determined both for the air and settled dust collected from the cattle breeding premises.

Microbiological contamination of the air was determined using a MAS-100 Eco ${ }^{\circledR}$ air sampler (Merck, Germany) according to the EN 13098 standard. Air samples of $10 \mathrm{~L}$, $20 \mathrm{~L}$ and $50 \mathrm{~L}$ were collected onto media presented in Table 2. Samples of air were collected from three locations at a height of $1.5 \mathrm{~m}$ during routine work. Atmospheric air samples (external background) were collected at a distance of $0.5 \mathrm{~km}$ from the tested building.

Table 1. Description of tested premises in cattle farm.

\begin{tabular}{|c|c|c|c|c|c|c|c|}
\hline Barn & $\begin{array}{l}\text { Building material } \\
\text { and room } \\
\text { description }\end{array}$ & $\begin{array}{l}\text { Dimensions* } \\
\text { (m) }\end{array}$ & $\begin{array}{l}\text { Cubature } \\
\left(\mathrm{m}^{3}\right)\end{array}$ & Ventilation & Feeding & Watering & $\begin{array}{l}\text { Manure } \\
\text { removal }\end{array}$ \\
\hline 1 & $\begin{array}{l}\text { Brick; } \\
\text { barn; } \\
11 \text { dairy cows, } \\
2 \text { dairy calves }\end{array}$ & $\begin{array}{l}5.33 \times 7.06 \times \\
2.61\end{array}$ & 237.33 & $\begin{array}{l}\text { Natural } \\
\text { (2 lockable doors and } \\
4 \text { windows) }\end{array}$ & Manual & Automatic & Automatic \\
\hline 2 & $\begin{array}{l}\text { Airbrick; } \\
\text { barn; } \\
18 \text { dairy cows, } \\
2 \text { dairy calves }\end{array}$ & $\begin{array}{l}6.96 \times 28.06 \\
\times 3.92\end{array}$ & 765.57 & $\begin{array}{l}\text { Natural and mechanical } \\
\text { ( } 2 \text { lockable doors, } \\
1 \text { permanently open door, } \\
1 \text { window, } 2 \text { ventilators) }\end{array}$ & $\begin{array}{l}\text { Half- } \\
\text { automatic }\end{array}$ & Automatic & Automatic \\
\hline 3 & $\begin{array}{l}\text { Airbrick; } \\
\text { barn; } \\
3 \text { dairy calves }\end{array}$ & $\begin{array}{l}4.69 \times 4.64 \times \\
2.30\end{array}$ & 50.05 & $\begin{array}{l}\text { Natural } \\
\text { (1 lockable door, } \\
1 \text { permanently open door) }\end{array}$ & Manual & Automatic & Manual \\
\hline 4 & $\begin{array}{l}\text { Airbrick; } \\
\text { barn; } \\
4 \text { dairy calves }\end{array}$ & $\begin{array}{l}4.69 \times 4.64 \times \\
2.30\end{array}$ & 50.05 & $\begin{array}{l}\text { Natural } \\
\text { (1 lockable door, } \\
1 \text { permanently open door) }\end{array}$ & Manual & Automatic & Manual \\
\hline 5 & $\begin{array}{l}\text { Wood; } \\
\text { barn; } \\
11 \text { beef cattle }\end{array}$ & $\begin{array}{l}13.24 \times 7.93 \\
\times 5.12\end{array}$ & 537.57 & $\begin{array}{l}\text { Natural } \\
\text { (2 lockable doors, } \\
1 \text { permanently open door) }\end{array}$ & Manual & Automatic & Manual \\
\hline 6 & $\begin{array}{l}\text { Brick; } \\
\text { milking parlour; } \\
\text { - }^{* *}\end{array}$ & $\begin{array}{l}2.67 \times 3.98 \times \\
2.39\end{array}$ & 25.40 & $\begin{array}{l}\text { Natural } \\
(2 \text { lockable doors and } \\
1 \text { window) }\end{array}$ & \multicolumn{3}{|c|}{$\begin{array}{l}\text { Milking machine, milk tank, sink, } \\
\text { cleaning products, table (animals } \\
\text { absent) }\end{array}$} \\
\hline
\end{tabular}

${ }^{*}$ Width $\times$ length $\times$ height. ${ }^{* *}$ Premises without animals.

Table 2. Media used in microbial contamination analysis.

\begin{tabular}{lll}
\hline Medium & Manufacturer (country) & Microorganisms \\
\hline Chapman Agar & Merck (Germany) & Mannitol-positive Staphylococcus sp. \\
Columbia Blood Agar & Oxoid (France) & Haemolytic staphylococcus \\
DG18 Agar (DG18 LAB-AGAR ${ }^{\mathrm{TM}}$ ) & Biocorp (Poland) & Xerophilic fungi \\
King B medium & Hi Media Laboratories (India) & Pseudomonas fluorescens \\
$\begin{array}{l}\text { Malt extract agar (MEA) medium with (0.1\%) } \\
\text { chloramphenicol }\end{array}$ & Merck (Germany) & Fungi \\
$\begin{array}{l}\text { Pochon's agar with (0.2\%) nystatin } \\
\text { Tryptic soy agar (TSA) with (0.2\%) nystatin }\end{array}$ & Labomix (Poland) & Actinomycetes \\
$\begin{array}{l}\text { Violet Red Bile Glucose Agar (VRBG LAB- } \\
\text { AGAR) }\end{array}$ & Biocorp (Poland) & Bacteria \\
\hline
\end{tabular}


Samples of settled dust from working environments were microbiologically analysed. For this purpose, 10-15 g of dust samples were collected in sterile containers, mixed, and $0.1 \mathrm{~g}$ of each of the mixed samples was suspended in $9.9 \mathrm{~mL}$ of saline solution $(0.85 \% \mathrm{NaCl})$. The samples were diluted from $10^{-2}$ to $10^{-6}$ in triplicates and plated onto media described above.

All samples (air, dusts) were incubated at either $37 \pm 2^{\circ} \mathrm{C}$ for $24-48 \mathrm{~h}$ (Enterobacteriaceae, mannitol-positive Staphylococcus sp.), $25 \pm 2{ }^{\circ} \mathrm{C}$ for 5-7 days (fungi, xerophilic fungi, actinomycetes), or $30 \pm 2^{\circ} \mathrm{C}$ for $48 \mathrm{~h}$ (bacteria, Pseudomonas fluorescens).

After incubation, the colonies were counted, and the

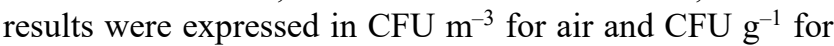
settled dust. The final result was calculated as the arithmetic mean of three independent repetitions.

\section{Assessment of Microbial Diversity by High-throughput Sequencing}

Air and dust samples for DNA extraction were collected from Barn 2. Air $(2000 \mathrm{~L})$ was passed through sterile gelatine filters ( $80 \mathrm{~mm}, 0.3 \mu \mathrm{L}$; Sartorius, Germany) using AirPort MD 8 (Sartorius, Germany). DNA was extracted from dust samples $(0.5 \mathrm{~g})$ and the gelatine filters $(0.5 \mathrm{~g})$ using the FastDNA ${ }^{\circledR}$ SPIN Kit (MP Biomedicals, USA), according to the manufacturer's protocol. DNA concentration was determined using a Qubit 2.0 Fluorometer (Invitrogen/Life Technologies, USA).

The bacterial 16S rRNA gene was amplified using primers $341 \mathrm{~F}$ and $785 \mathrm{R}$ targeting the V3-V4 regions. The fungal ITS1 region was amplified with ITS1F12 (forward) (Schmidt et al., 2013) and ITS2 (reverse) primers (White et al., 1990). All polymerase chain reactions were performed in $50 \mu \mathrm{L}$ volumes, containing $5 \mu \mathrm{L}$ of DNA as a template, $25 \mu \mathrm{L}$ of DreamTaq $^{\mathrm{TM}}$ Hot Start DNA Polymerase $(2 \times$ master mix; Thermo Fisher Scientific, USA) and 10 pmol of relevant reverse and forward primers. The amplification of bacterial and fungal fragments was performed under the same conditions, with an initial denaturation at $95^{\circ} \mathrm{C}$ for $2 \mathrm{~min}$, followed by 25 cycles of denaturation at $95^{\circ} \mathrm{C}$ for $30 \mathrm{~s}$, annealing at $55^{\circ} \mathrm{C}$ for $30 \mathrm{~s}$, and extension at $72^{\circ} \mathrm{C}$ for $1 \mathrm{~min}$, with a final extension at $72^{\circ} \mathrm{C}$ for $5 \mathrm{~min}$. DNA libraries were constructed using the Nextera Index Kit (Thermo Fisher Scientific, USA) according to the library preparation protocol for short amplicons $(2 \times 250 \mathrm{bp})$ provided by the manufacturer. Paired-end (PE; $2 \times 250 \mathrm{nt}$ ) sequencing was performed on the Illumina MiSeq (MiSeq Reagent Kit v2) according to the manufacturer's protocol (Illumina, Inc., USA) at Genomed (Poland).

QIIME was used to determine different types of microbial communities in the analysed dust and air (Caporaso et al., 2010). The raw reads were demultiplexed and quality-filtered on MiSeq using MiSeq Reporter (MSR) v2.4 (Illumina, Inc., USA). The sequences were clustered (8 taxonomic classifications) based on $97 \%$ identity using the uclust algorithm (Edgar, 2010), and operational taxonomic units (OTUs) were assigned to taxa employing the GreenGenes database v13_8 for bacteria and UNITE v8 database for fungi (Kõljalg et al., 2013).

\section{Analysis of Endotoxin in Dust Samples}

3-Hydroxy fatty acids (3-OH FAs), which are unique compounds within the conserved portion of lipopolysaccharides (LPS), were used to identify endotoxins in settled dust samples from the cattle farm. Samples were subjected to hydrolysis prior to 3-OH FA release, and the subsequent steps were performed as described earlier (Sebastian and Larsson, 2003). Products of the reaction were measured using GC-MS, and the results were expressed in nmol of LPS per mg of dust.

\section{Secondary Metabolites}

For secondary metabolite analyses, air samples (2000 L) from gelatine filters and $1 \mathrm{~g}$ of dust were dissolved in 8 and $10 \mathrm{~mL}$ extraction solvent (acetonitrile:water:acetic acid $=$ 79:20:1 v/v/v), respectively. Next dust and air samples were extracted for $90 \mathrm{~min}$ and diluted in the same volume of solvent prior to injection (Sulyok et al., 2006). Secondary metabolite concentrations were analysed and quantified using LC-MS/MS, as described by Sulyok et al. (2007) with further modification. Parameters for liquid chromatography and mass spectrometry are described elsewhere (Malachová et al., 2014). Briefly, LC-MS/MS screening of target microbial metabolites was performed with a QTrap 5500 LC-MS/MS System (Applied Biosystems, USA) equipped with a TurboIonSpray electrospray ionization (ESI) source and a 1290 Series HPLC System (Agilent, Germany). Chromatographic separation was performed at $25^{\circ} \mathrm{C}$ on a Gemini ${ }^{\circledR}$ C18 column $(150 \times 4.6 \mathrm{~mm}$ i.d., $5 \mathrm{~mm}$ particle size) equipped with a $\mathrm{C} 18(4 \times 3 \mathrm{~mm}$ i.d. $)$ security guard cartridge (Phenomenex, USA). ESI-MS/MS was performed in the time-scheduled multiple reaction monitoring (MRM) mode, both in positive and negative polarities, in two separate chromatographic runs per sample, by scanning two fragmentation reactions per analyte. The MRM detection window of each analyte was set to its expected retention times of \pm 27 and $\pm 48 \mathrm{~s}$ in the positive and negative modes, respectively. The positive analyte was confirmed by the acquisition of two MRMs per analyte, with the exception of moniliformin, which exhibited only one fragment ion. This yielded 4.0 identification points according to European Union Commission Decision 2002/657 (Commission Decision 96/23/EC; European Commission, 2002). The LC retention time and the intensity ratio of the two MRM transitions agreed with the related values of an authentic standard within $0.1 \mathrm{~min}$ and $30 \%$ rel. Analysis was performed in three replicates per sample.

The limits of detection (LODs) of extrolites are presented in Table S1.

\section{Cell Culture and Cytotoxicity Testing}

For cell culturing (described later), $1.0 \mathrm{~g}$ of each dust sample was suspended in $10 \mathrm{~mL}$ of basal medium and mixed (stock dust concentration in each extract was $100 \mathrm{mg} \mathrm{mL}^{-1}$ ). The samples were then extracted for $40 \mathrm{~min}\left(160 \mathrm{rev} \mathrm{min}^{-1}\right)$ at ambient temperature. Since alkaline or acidic $\mathrm{pH}$ of the test sample can negatively influence cell growth and adherence, the $\mathrm{pH}$ of each extract was adjusted to neutral $(7.0 \pm 0.2)$. Each extract was filtered twice using sterile 
syringe filters $(0.22 \mathrm{~m})$ (Membrane Solutions, USA). The final concentrations of the extracts analysed were $20,10,5$, 2.5, $1.3,0.6$ and $0.3 \mathrm{mg} \mathrm{mL}^{-1}$.

The cytotoxicity of the prepared water-soluble fraction of dust samples was assessed using the MTT [3-(4,5dimethylthiazol-2-yl)-2,5-diphenyltetrazolium bromide] assay. The assay was performed on the human adenocarcinoma lung (alveolar) epithelial adherent cell line A-549 (Cell Line Service GmbH, Germany) from passage 33. The model cell line is often used for dust and air pollution cytotoxicity testing (Gutarowska et al., 2018).

The cells were cultured as previously described (Gutarowska et al., 2018). Briefly, they were cultured as a monolayer in Dulbecco's Modified Eagle's Medium: Ham's F12 basic (1:1 v/v, DMEM/Ham's F12; Cell Line Service GmbH, Germany) supplemented with 5\% foetal bovine serum (FBS; Cell Line Service GmbH, Germany), $2 \mathrm{mM}$ of glutamine (Cell Line Service GmbH, Germany), $25 \mathrm{mM}$ of HEPES (Cell Line Service GmbH, Germany), and $100 \mu \mathrm{g} \mathrm{mL}{ }^{-1}$ streptomycin and $100 \mathrm{IU} \mathrm{mL}^{-1}$ penicillin mixture (SigmaAldrich, USA). The cells were cultured for $3-5$ days at $37^{\circ} \mathrm{C}$ in an incubator with $5 \% \mathrm{CO}_{2}$ atmosphere (Galaxy $48 \mathrm{~S}$, United Kingdom). After reaching 80\% confluence, the cells were detached using Gibco TrypLETM Express (Thermo Fisher Scientific, USA), centrifuged $(187 \times \mathrm{g}, 5 \mathrm{~min})$ and the pellet was re-suspended in fresh culture medium. Subsequently the number of cells were counted using a haemocytometer. The viability of the cells was determined by trypan blue exclusion. The cells were only used if they showed a minimum of $80-90 \%$ viability.

For both MTT assays, $1 \times 10^{4}$ A-549 cells were placed in each well of a 96 well plate (Greiner Bio-One $\mathrm{GmbH}$, Germany) in the complete culture medium. The cells were incubated overnight at $37^{\circ} \mathrm{C}$ in $5 \% \mathrm{CO}_{2}$. The following day, the medium was gently aspirated, and $200 \mu \mathrm{L}$ of each concentration of the tested extract in the culture medium was added to wells in the 96 well plate in four repeats. The negative controls (in eight repeats) consisted of cells without tested extracts. The cells were incubated in $\mathrm{a} \mathrm{CO}_{2}$ incubator at $37^{\circ} \mathrm{C}$ in $5 \% \mathrm{CO}_{2}$ for 48 and $72 \mathrm{~h}$. After incubation, the samples were gently aspirated, $100 \mu \mathrm{L}$ of MTT $\left(0.5 \mathrm{mg} \mathrm{mL}^{-1}\right.$ in PBS,
pH: 7.2) (Sigma-Aldrich, USA) was added and they were further incubated at $37^{\circ} \mathrm{C}$ in $5 \% \mathrm{CO}_{2}$ for an additional $3 \mathrm{~h}$. Then MTT was carefully removed and formazan precipitates were solubilised by adding $50 \mu \mathrm{L}$ of DMSO (Sigma-Aldrich, USA). Absorbance was measured at $550 \mathrm{~nm}$ with a reference filter of $620 \mathrm{~nm}$, using a microplate reader (TriStar2 LB 942; Berthold Technologies GmbH and Co. KG, Germany). The absorbance of the control sample (untreated cells) represented $100 \%$ cell viability. Cell viability (\%) was calculated using the following equation: (sample OD/control OD) $\times 100 \%$; the cytotoxicity $(\%)$ was calculated as: 100 - cell viability $(\%)$. The results are presented as mean \pm standard deviation (SD). The mean error of these methods is up to $10 \%$.

The $\mathrm{IC}_{50}$ value (the concentration of the test compound required to reduce the cell survival rate to $50 \%$ of the control) is the degree of cellular sensitivity to a given treatment. $\mathrm{IC}_{50}$ values were determined both from the plotted curves and according to the OECD Guidelines for the Testing of Chemicals (GESTIS, 2018; OECD, 2018).

\section{Statistical Analysis}

Statistical analyses were conducted using Statistica 13.1 (Statsoft, USA). Descriptive statistics for all variables of interest were calculated. Microorganism numbers in the air and dust samples as well as microclimatic conditions and dust concentrations were compared between the tested locations using one-way analysis of variance (ANOVA) at a significance level of 0.05 following Levene's test. When a statistical difference was detected $(p<0.05)$, means were compared using Tukey's post hoc procedure at 0.05 significance level.

Linear regression analysis was used to determine the correlation between the number of microorganisms in the air and settled dust at particular locations within the cattle farm. The significance tests were performed at the 0.05 significance level using a literature correlation scale (Hinkle et al., 2003).

\section{RESULTS AND DISCUSSION}

\section{Microclimatic Conditions}

Microclimatic conditions present in the cattle farm are presented in Table 3.

Table 3. Microclimatic conditions during measurements at the tested workplaces.

\begin{tabular}{llll}
\hline Barn & Temperature $\left({ }^{\circ} \mathrm{C}\right)$ & Relative humidity $(\%)$ & Air flow velocity $\left(\mathrm{m} \mathrm{s}^{-1}\right)$ \\
\hline 1 & M: $11.6^{\mathrm{ab}}$ & M: $52.4^{\text {ad }}$ & M: $0.15^{\mathrm{a}}$ \\
& SD: 1.0 & SD: 2.8 & SD: 0.09 \\
M: $10.9^{\mathrm{b}}$ & M: $57.8^{\mathrm{b}}$ & M: $0.40^{\mathrm{b}}$ \\
3 & SD: 0.4 & SD: 1.2 & SD: 0.04 \\
& M: $12.5^{\mathrm{a}}$ & M: $56.7^{\mathrm{ab}}$ & M: $0.62^{\mathrm{c}}$ \\
4 & SD: $0.2^{\mathrm{a}}$ & SD: 1.3 & SD: 012 \\
& M: $12.9^{\mathrm{a}}$ & M: $57.3^{\mathrm{ab}}$ & M: $0.03^{\mathrm{a}}$ \\
5 & SD: 0.2 & SD: 1.7 & SD: 0.01 \\
& M: $14.6^{\mathrm{c}}$ & M: $49.7^{\mathrm{cd}}$ & M: $0.03^{\mathrm{a}}$ \\
6 & SD: 0.8 & SD: 1.6 & SD: 0.01 \\
& M: $16.4^{\mathrm{d}}$ & M: $45.5^{\mathrm{c}}$ & M: $0.01^{\mathrm{a}}$ \\
& SD: 0.2 & SD: 2.6 & SD: 0.01 \\
\hline
\end{tabular}

M: mean; SD: standard deviation. Statistically significant differences (ANOVA: $p<0.05$; Tukey's test: $p<0.05$ ) occur for means marked with different letters ( $a, b, c, d)$ within the same parameter (column). 
The air temperature in the barns ranged from $10.9^{\circ} \mathrm{C}$ (Barn 2) to $16.4^{\circ} \mathrm{C}$ (Barn 6, the milking parlour). We also found the highest $(57.8 \%)$ and lowest $(45.5 \%)$ relative humidity in these rooms compared to the rest of the farm. Airflow rate ranged from $0.01 \mathrm{~m} \mathrm{~s}^{-1}$ (Barn 6) to $0.62 \mathrm{~m} \mathrm{~s}^{-1}$ (Barn 3) (Table 3).

Microclimatic conditions in individual barns varied considerably; statistically significant differences were found even for contiguous areas (e.g., between Barns 3 and 4 as well as 2). Despite open doors and windows, low airflow rates were observed in the majority of the barns, which hampered air exchange with the surroundings. Statistically significant differences in this parameter were noted between Barns 2 and 3 , and the rest of the farm complex, which was probably due to the presence of doors and windows along the lengths of the buildings. Different values of individual microclimatic parameters indicate that in individual barns there could be completely different conditions for microorganism growth.

\section{Dust Concentrations at Workplaces}

Total dust concentrations in the barns varied; high values were noted in Barns 1 and $6\left(0.281\right.$ and $0.351 \mathrm{mg} \mathrm{m}^{-3}$, respectively), while the remaining barns had lower values (from 0.175 to $0.265 \mathrm{mg} \mathrm{m}^{-3}$ ) (Table 4). In all barns, the predominant dust fraction had an aerodynamic diameter $<1 \mu \mathrm{m}$. The share of the total amount of dust measured ranged from $67.4 \%$ in Barn 1 to $96.4 \%$ in Barn 5. The smallest fraction (0.4-3.4\%) amongst the total dust collected consisted of particles of diameters ranging from 1 to $4 \mu \mathrm{m}$.

The dust concentration values shown in Table 4 did not exceed the threshold limits for workplaces according to national legislation. Hence, it is not a regulatory requirement to use respiratory protective equipment, and the use of such equipment is purely voluntary. Selecting appropriate equipment depends, in this case, on an individual user's comfort. Workers can decide to use any half mask, regardless of its protection class.

\section{Microbial Contamination}

The number of bacteria on cattle breeding premises ranged from $7.14 \times 10^{3} \mathrm{CFU} \mathrm{m}^{-3}$ (Barn 3) to $3.88 \times 10^{4} \mathrm{CFU} \mathrm{m}^{-3}$ (Barn 2). The number of Actinobacteria were lower and ranged from $2.25 \times 10^{1} \mathrm{CFU} \mathrm{m}^{-3}$ (Barn 6) to $3.45 \times 10^{4} \mathrm{CFU} \mathrm{m}^{-3}$ (Barn 4). The concentration of mannitol-positive Staphylococci ranged from $1.80 \times 10^{2} \mathrm{CFU} \mathrm{m}^{-3}$ (Barn 6) to $8.30 \times 10^{3}$ CFU m ${ }^{-3}$ (Barn 1) (Table 5). In turn, the number of bacteria from the family Enterobacteriaceae was $5.75 \times 10^{1} \mathrm{CFU} \mathrm{m}^{-3}$ in Barn 6 and $7.05 \times 10^{2} \mathrm{CFU} \mathrm{m}{ }^{-3}$ in Barns 1 and 2 . Haemolytic Staphylococci were most abundant in Barn 2 $\left(3.3 \times 10^{2} \mathrm{CFU} \mathrm{m}^{-3}\right)$, while Barn 1 had the fewest $(3.25 \times$ $10^{1} \mathrm{CFU} \mathrm{m}^{-3}$ ). Pseudomonas fluorescens bacteria in the barns was the lowest of all microorganism groups studied and ranged from $2.50 \times 10^{0}$ to $1.00 \times 10^{1} \mathrm{CFU} \mathrm{\textrm {m } ^ { - 3 }}$. Fungi number in the barns studied ranged from $5.53 \times 10^{1} \mathrm{CFU} \mathrm{m}^{-3}$ (Barn 6) to $1.30 \times 10^{4} \mathrm{CFU} \mathrm{m}^{-3}$ (Barn 2) and xerophilic fungi from $6.5 \times 10^{2} \mathrm{CFU} \mathrm{m}^{-3}$ (Barn 6) to $6.1 \times 10^{3} \mathrm{CFU} \mathrm{m}^{-3}$ (Barn 1) (Table 5).

Statistically significant differences in microorganism numbers, with the exception of total bacteria number and the number of Pseudomonas fluorescens, were observed between the air of the barns and atmospheric air (control sample) sampled at a distance of $500 \mathrm{~m}$ from farm buildings. Thus, the highest microbiological air contamination was detected in Barns 1-4, and the lowest in Barns 5 and 6, where the number of microorganisms was most often comparable to atmospheric air. Barns 5 and 6 also had the lowest relative humidity $(<50 \%)$. Furthermore, Barn 6 , as the milking parlour, was maintained under good hygienic conditions, where no animals were present; this probably explains the lower air contamination observed.

We found lower microorganism numbers in the air than previously observed by Dutkiewicz et al. (1994). These authors detected bacterial numbers ranging between $4.4 \times$ $10^{4}$ and $2.8 \times 10^{5} \mathrm{CFU} \mathrm{m}^{-3}$ in dairy barns and calf barns, and fungal numbers from $1.0 \times 10^{3}$ to $6.1 \times 10^{4} \mathrm{CFU} \mathrm{m}^{-3}$. The authors conducted the studies in premises housing 42-137 animals, which may have resulted in obtaining higher microorganism numbers in the air. Unfortunately, we do not know the dimensions of the premises investigated, which would have helped determine animal density per unit

Table 4. Airborne dust concentrations at tested premises.

\begin{tabular}{|c|c|c|c|c|c|}
\hline \multirow{2}{*}{ Barn } & \multicolumn{5}{|c|}{ Airborne dust concentrations corresponding to particle size fractions $\left(\mathrm{mg} \mathrm{m}^{-3}\right)$} \\
\hline & $\mathrm{PM}_{1}$ & $\mathrm{PM}_{2.5}$ & $\mathrm{PM}_{4}$ & $\mathrm{PM}_{10}$ & $\mathrm{PM}_{\text {total }}$ \\
\hline \multirow[t]{2}{*}{1} & M: $0.190^{\mathrm{b}}$ & M: $0.191^{\mathrm{b}}$ & M: $0.194^{\mathrm{b}}$ & M: $0.224^{\mathrm{c}}$ & M: $0.281^{\mathrm{b}}$ \\
\hline & SD: 0.297 & SD: 0.298 & SD: 0.304 & SD: 0.403 & SD: 0.676 \\
\hline \multirow[t]{2}{*}{2} & M: $0.193^{\mathrm{b}}$ & M: $0.195^{\mathrm{b}}$ & M: $0.204^{\mathrm{b}}$ & M: $0.244^{\mathrm{b}}$ & M: $0.265^{b}$ \\
\hline & SD: 0.099 & SD: 0.104 & SD: 0.130 & SD: 0.263 & SD: 0.276 \\
\hline \multirow[t]{2}{*}{3} & M: $0.265^{\mathrm{b}}$ & $M: .163^{d}$ & M: $0.164^{d}$ & M: $0.170^{\mathrm{d}}$ & M: $0.175^{\mathrm{c}}$ \\
\hline & SD: 0.276 & SD: 0.033 & SD: 0.034 & SD: 0.036 & SD: 0.045 \\
\hline \multirow[t]{2}{*}{4} & M: $0.169^{\mathrm{cd}}$ & M: $0.170^{\text {cd }}$ & M: $0.171^{\mathrm{cd}}$ & M: $0.171^{\mathrm{cd}}$ & M: $0.178^{\mathrm{c}}$ \\
\hline & SD: 0.024 & SD: 0.024 & SD: 0.024 & SD: 0.024 & SD: 0.039 \\
\hline \multirow[t]{2}{*}{5} & M: $0.177^{\mathrm{c}}$ & M: $0.178^{c}$ & M: $0.178^{c}$ & M: $0.181^{\mathrm{d}}$ & M: $0.184^{\mathrm{c}}$ \\
\hline & SD: 0.013 & SD: 0.013 & SD: 0.013 & SD: 0.017 & SD: 0.028 \\
\hline \multirow[t]{2}{*}{6} & M: $0.303^{\mathrm{a}}$ & $M: 0.304^{\mathrm{a}}$ & M: $0.307^{\mathrm{a}}$ & M: $0.330^{\mathrm{a}}$ & M: $0.351^{\mathrm{a}}$ \\
\hline & SD: 0.023 & SD: 0.023 & SD: 0.024 & SD: 0.038 & SD: 0.059 \\
\hline
\end{tabular}

M: mean; SD: standard deviation. Statistically significant differences (ANOVA: $p=0.05$; Tukey's test: $p=0.05$ ) occur for averages marked with different letters $(a, b, c, d)$ within the same dust fraction. 


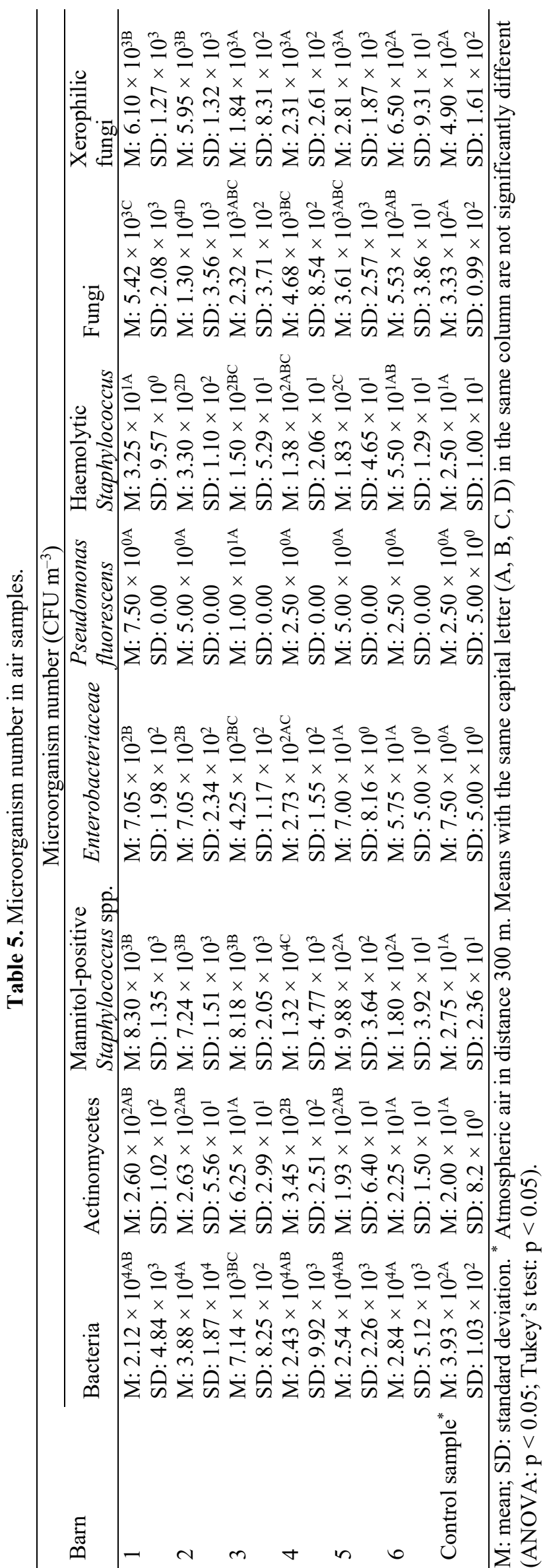

volume. Moreover, the microclimatic conditions under which the study was conducted are also not known.

Our work was carried out during winter/early spring, which is not conducive to microorganism survival in the air. Like us, Lee et al. (2006) conducted studies in a dairy farm during winter, and found a similar number of microorganisms as in our study. They obtained $0.3 \times 10^{3}-1.3 \times 10^{4} \mathrm{CFU} \mathrm{m}^{-3}$ for bacteria and $0.3 \times 10^{3}-3.9 \times 10^{4} \mathrm{CFU} \mathrm{m}^{-3}$ for fungi.

Lange et al. (1997) studied bioaerosol concentrations in 48 dairy barns. They showed that concentrations of individual microorganism groups differed by two to three orders of magnitude between the barns. They demonstrated that, of all farm management practices, the type of fodder was the strongest correlate of microorganism concentration; feeds with a high moisture content were associated with lower concentration of bioaerosols. In addition, the authors proved that the type of ventilation influences dust, endotoxin and gramnegative bacteria concentrations in barns (Lange et al., 1997).

In dust samples, bacteria prevailed $\left(5.97 \times 10^{7}-5.84 \times 10^{8}\right.$ CFU $\mathrm{g}^{-1}$ ), amongst which mannitol-positive Staphylococci $\left(2.35 \times 10^{7}-7.78 \times 10^{8} \mathrm{CFU} \mathrm{\textrm {g } ^ { - 1 }}\right)$ and bacteria from the family Enterobacteriaceae $\left(9.08 \times 10^{4}-1.72 \times 10^{5} \mathrm{CFU} \mathrm{g}^{-1}\right)$ were the most abundant (Table 6). Haemolytic Staphylococci $\left(3.15 \times 10^{4}-5.20 \times 10^{5} \mathrm{CFU} \mathrm{g}^{-1}\right)$ and Actinomycetes $(1.40 \times$ $10^{3}-4.45 \times 10^{4} \mathrm{CFU} \mathrm{g}^{-1}$ ) were less abundant in dust. In all samples of dust, no Pseudomonas fluorescens was detected (below the method's threshold for detection). The overall fungal numbers in dust samples tested amounted to $5.20 \times$ $10^{5}-4.44 \times 10^{7} \mathrm{CFU} \mathrm{g}^{-1}$, with xerophilic fungal numbers between $1.22 \times 10^{6}-1.53 \times 10^{7} \mathrm{CFU} \mathrm{g}^{-1}$ (Table 6).

Statistical analysis found that the most microbiologically contaminated dust samples were from Barns 2 and 3, while the least was from Barns 4 and 5, which also had the lowest concentration of microorganisms in the air.

There are no data in the literature on microorganism numbers in sedimented dust from cattle breeding premises. In a previous study, we carried out an analogous analysis on sedimented dust from agricultural work environment (dust from poultry breeding premises and grain dust). We found similar bacterial numbers in dust from that work environment $\left(3.33 \times 10^{7}-1.57 \times 10^{8} \mathrm{CFU} \mathrm{g}^{-1}\right)$. There were less actinomycetes $\left(\leq 2.05 \times 10^{3} \mathrm{CFU} \mathrm{g}^{-1}\right)$, mannitolpositive Staphylococci $\left(1.20 \times 10^{4}-3.49 \times 10^{4} \mathrm{CFU} \mathrm{g}^{-1}\right)$, Enterobacteriaceae $\left(\leq 2.30 \times 10^{4} \mathrm{CFU} \mathrm{g}^{-1}\right)$, fungi $(7.48 \times$ $\left.10^{4}-8.75 \times 10^{5} \mathrm{CFU} \mathrm{g}^{-1}\right)$ and xerophilic fungi $\left(3.35 \times 10^{5}-\right.$ $\left.4.45 \times 10^{5} \mathrm{CFU} \mathrm{g}^{-1}\right)$. However, there were more $P$. fluorescens $\left(1.00 \times 10^{5}-5.73 \times 10^{5} \mathrm{CFU} \mathrm{g}^{-1}\right)$. The number of haemolytic Staphylococci was higher in poultry farm dust $\left(8.50 \times 10^{5}\right.$ $\left.\mathrm{CFU} \mathrm{g} \mathrm{g}^{-1}\right)$ and lower in grain dust $\left(2.98 \times 10^{3} \mathrm{CFU} \mathrm{g}^{-1}\right)$ (Skóra et al., 2016; Gutarowska et al., 2018). Considering the above, dust from cattle breeding premises was more microbiologically contaminated than dust from poultry breeding premises and grain dust.

In the current study, we saw strong positive correlations $\left(\mathrm{R}^{2}=0.8349-0.9471\right)$ between microorganism numbers in the air and dust from the cattle farm (Fig. 1).

\section{Diversity of Microorganisms from the Cattle Farm}

High-throughput DNA sequencing data (Figs. 2 and 3; 


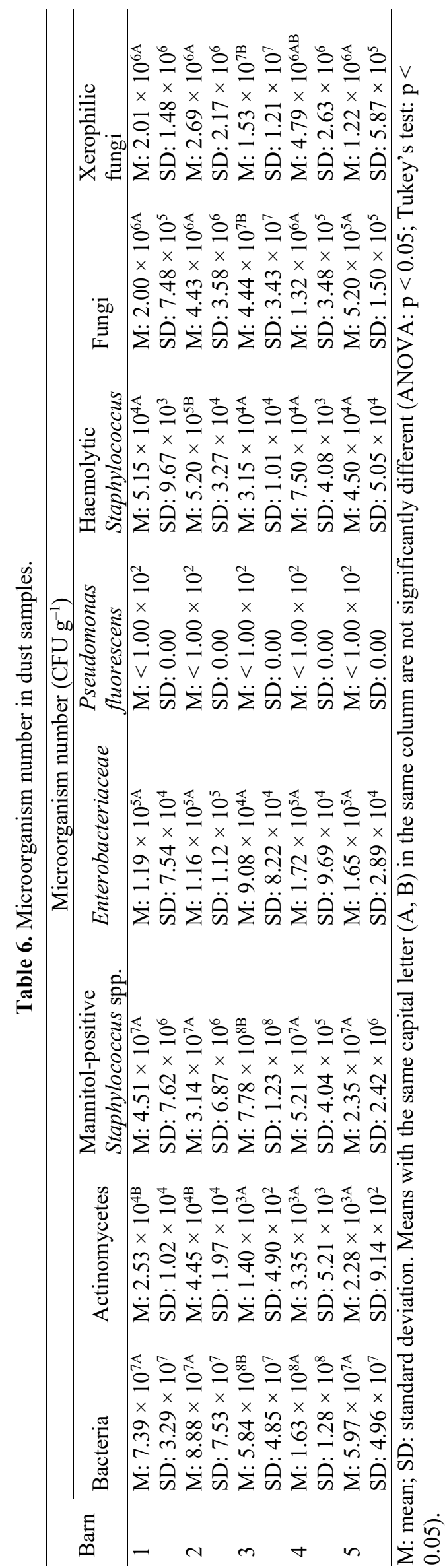

Tables S2 and S3) shows the phylogenetic diversity of microorganisms that were present in the dust and air collected in Barn 2. We found a prevalence of 172 bacterial/archaeal genera, from 10 phyla, and 89 fungal genera from 6 phyla, in the dust. In addition, 210 bacterial/archaeal genera (10 phyla) and 43 fungal genera (6 phyla) were identified in the air.

Both samples (dust and air) were mainly contaminated with bacteria belonging to Firmicutes (85.8 and $46.2 \%$ ), Proteobacteria (4.1 and $15.9 \%$ ), Actinobacteria (4.7 and 13.8\%), and Bacteroidetes (4.2 and 13.8\%) (Fig. 2). Firmicutes from the dust sample mainly consisted of bacteria from the genera Staphylococcus (74.4\%), Ruminococcus (3.3\%), Clostridium (1.9\%) and Abiotrophia (1.3\%). Bacteria belonging to Corynebacterium (2.6\%) dominated phylum Actinobacteria, while, in the case of Bacteroidetes, the most frequently occurring genus was Bacteroides (1.8\%). Additionally, Sphingomonas (1.5\%) was the most widespread genus among Proteobacteria. Amongst bacterial genera identified in the air, Actinomyces (2.8\%), Corynebacterium $(8.8 \%)$ and Saccharopolyspora (1.5\%) belonging to Actinobacteria; Bacteroides (5.6\%) and Paludibacter (1.2\%) belonging to phylum Bacteroidetes; Halomonas (3.1\%), Sphingomonas (1.8\%) and Ehrlichia (1.3\%) from phylum Proteobacteria; Acholeplasma (1.8\%) from Tenericutes; and Ruminococcus (11.4\%), Clostridium (6.2\%), Abiotrophia (4.7\%), Facklamia (4.0\%), Staphylococcus (3.3\%), Psychrobacter (2.3\%), Jeotgalicoccus (1.2\%), Aerococcus (1.4\%), and Acinetobacter (1.2\%) from Firmicutes were identified in abundance at a concentration $>1 \%$.

Ascomycota and Basidiomycota were the most abundant fungi in both samples (Fig. 3). In the dust sample, Ascomycota (41.6\% of phylum OTUs), Aspergillus (23.2\%), Cladosporium (6.1\%), Mycosphaerella (3.6\%), Alternaria (1.9\%), Candida $(2.6 \%)$ and Debaryomyces $(2.0 \%)$ had the highest OTUs. Additionally, members of Wallemia (38.8\%) dominated among Basidiomycota (41.7\% of phylum OTUs). Amongst fungi found in the air sample, DNA sequences associated with the genera Mycosphaerella (15.2\%), Alternaria (5.6\%), Aspergillus (7.8\%), Debaryomyces (3.0\%) and Candida $(8.3 \%)$ were mainly detected. Simultaneously, Fusarium was identified both in the air ( $2.0 \%$ of all genera's OTUs) and dust $(0.2 \%$ of OTUs). All of the above genera contaminating the air were from the phylum Ascomycota.

This is the first detailed study that describes the bacterial and fungal diversity in agricultural work environments. High-throughput sequencing analyses of air and dust samples, collected in Barn 2, found a variety of pathogens that may affect human and cattle health. Both dust and air were carriers of bacteria belonging to Corynebacterium sp. This genus was represented mostly by the species $C$. bovis, C. durum, C. kroppenstedtii, C. pilosum and C. variabile, which are responsible for infections of the respiratory tract, eye and soft facial tissue (Riegel et al., 1997; Berard, 2012; Chow et al., 2015). In addition, previous work found that patients suffering from mastitis, caused by $C$. kroppenstedtii, show symptoms of psychiatric illnesses. This fact was potentially associated with the infection promoted by this bacterium (Wong et al., 2017). The risk of airborne transmission of invasive multidrug-resistant strains is related to 

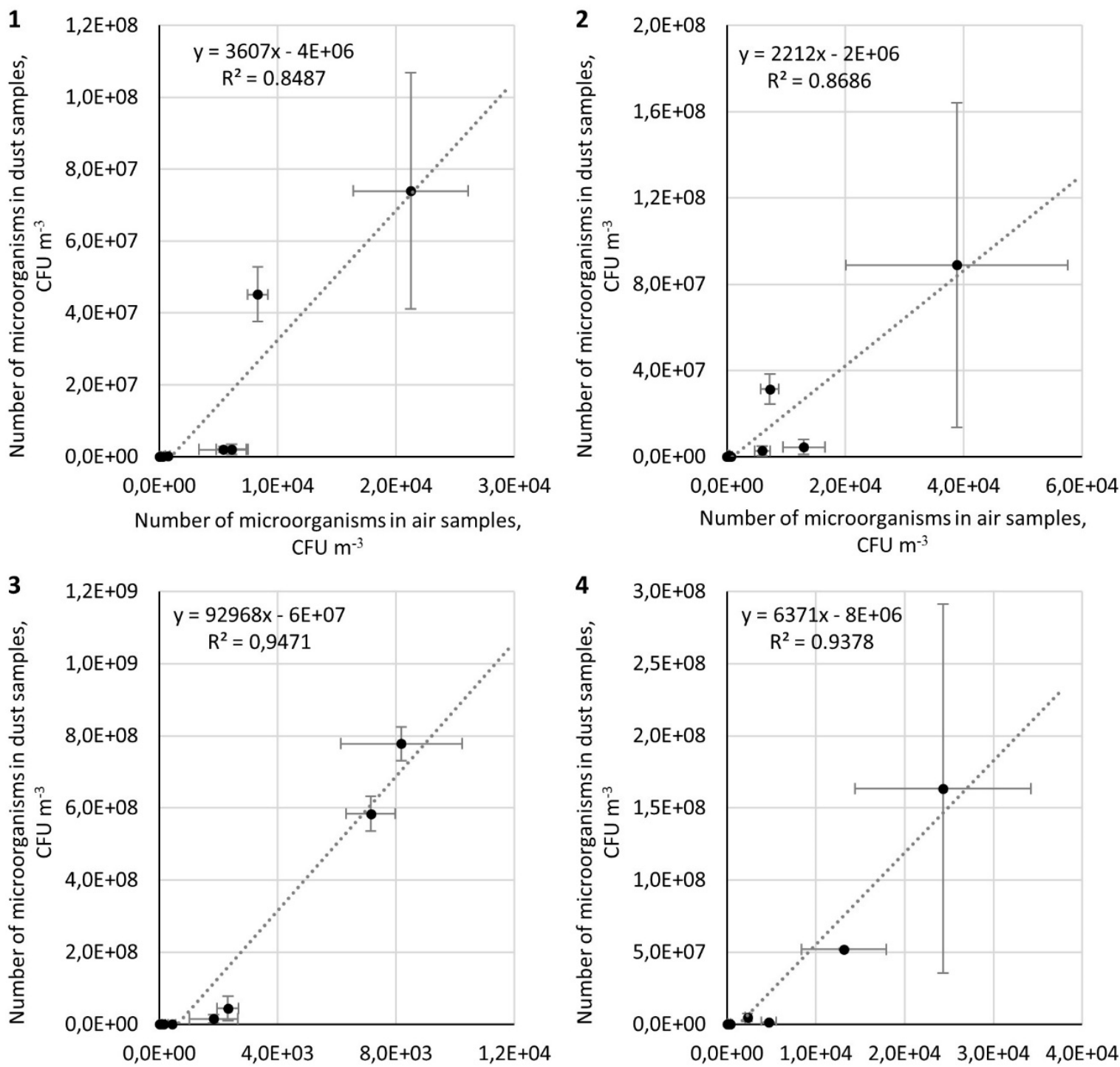

Number of microorganisms in air samples, $\mathrm{CFU} \mathrm{m}^{-3}$

Number of microorganisms in air samples, CFU $\mathrm{m}^{-3}$

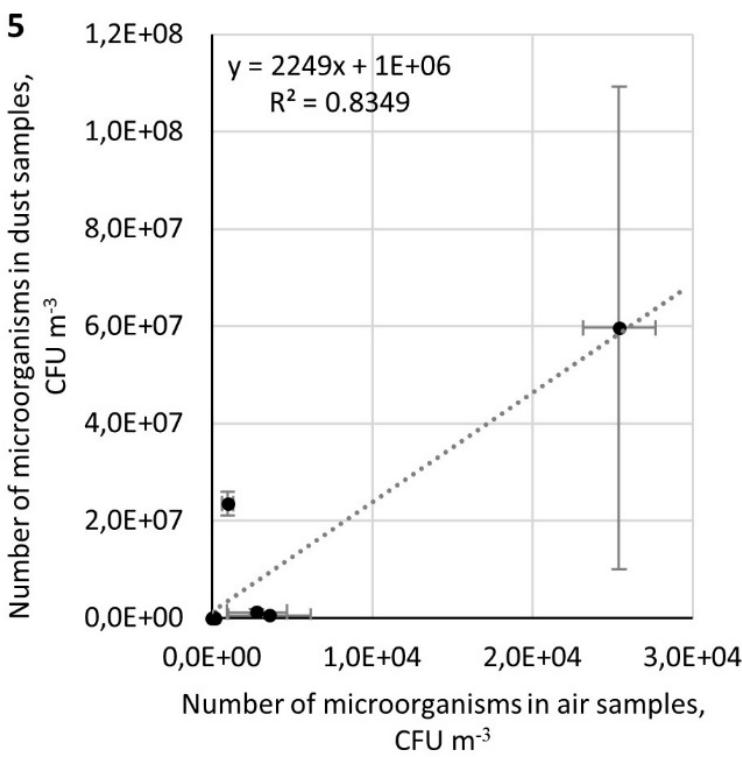

Fig. 1. Correlation between number of microorganisms in the air and dust samples. 1-5: Barn number. 


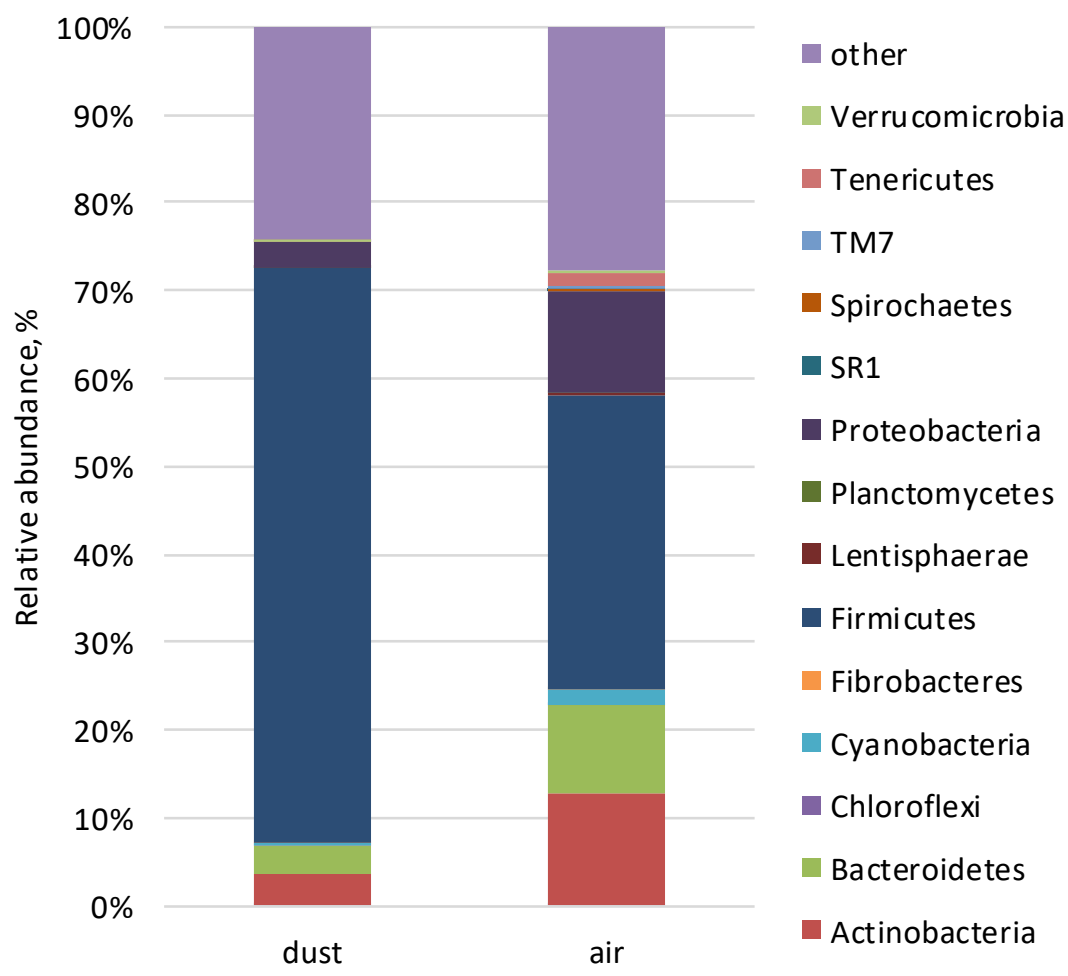

Fig. 2. Phylogenetic distribution of bacterial sequences assigned on phyla in dust and air samples.

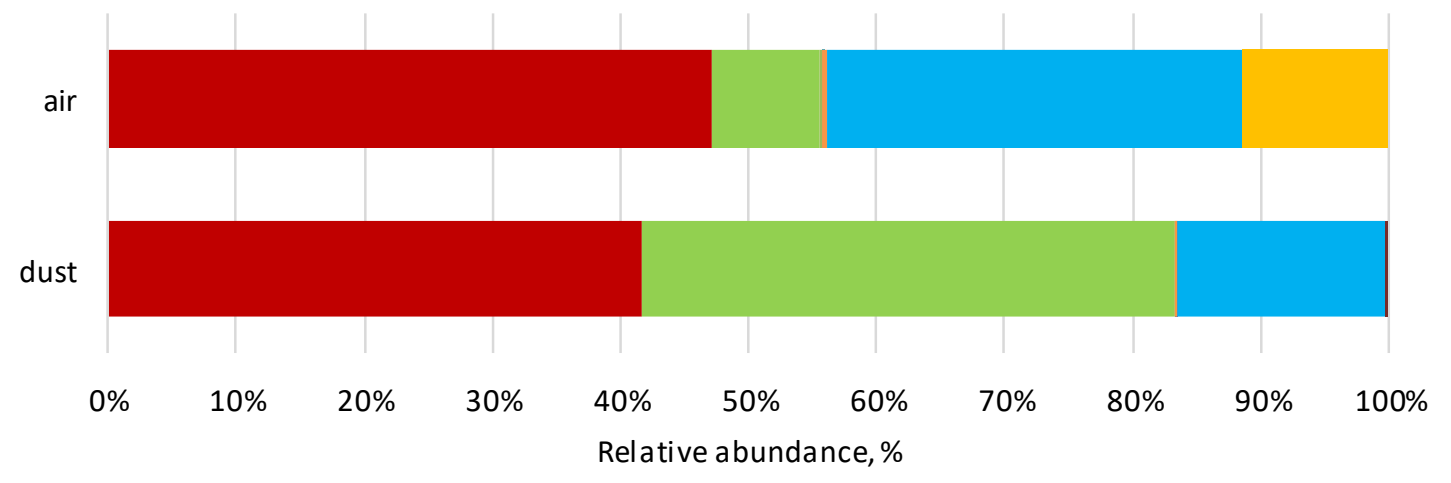

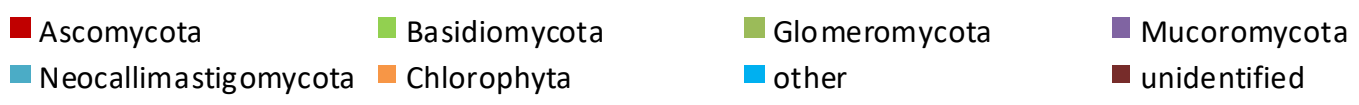

Fig. 3. Phylogenetic distribution of fungal sequences assigned to phyla in dust and air samples.

the presence of bacteria belonging to Staphylococcus sp. Staphylococci are typical components of natural microflora of feathers, skin, hair and mucous membranes. Other species in this genus, such as $S$. sciuri, S. equorum and $S$. epidermidis, can be pathogenic to humans and are responsible for endocarditis, urinary tract infections, pelvic inflammatory disease, wound infections and septic shock (Chen et al., 2007). Bacteroides fragilis, identified both in air and dust samples, is a known gram-negative rod involved in anaerobic infections (Wexler, 2007). Ruminococcus sp., identified in air, was reportedly found in the gastrointestinal tracts of animals and humans, and may be a factor for serious arthritis and bacteremia (Titecat et al., 2014). What is more, representatives of Aspergillus sp. (mainly A. fumigatus, A. conicus, $A$. penicillioides, A. proliferans, A. quadrilineatus and $A$. restrictus) were found in high relative abundance in dust and air. Amongst species of this genus, A. fumigatus is a serious human pathogen being the major cause of invasive aspergillosis (McCormick et al., 2010; Kwon-Chung and Sugui, 2013). Moulds belonging to Cladosporium sp., which are common saprobic fungi or plant endophytes, are associated with human diseases and allergies (Sandoval-Denis et al., 2016). Yeast Debaryomyces sp., which are considered a potential biocontrol agent against a number of moulds in food production, may cause human infections (DesnosOllivier et al., 2008). 


\section{Endotoxin Concentrations}

Endotoxin content in sedimented dust from the barns of cattle farms is shown in Fig. 4.

Endotoxin concentrations in sedimented dust ranged from

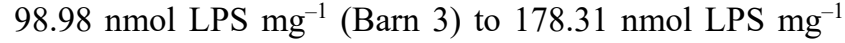
(Barn 4) (Fig. 4). Similar values of LPS concentrations were previously reported in literature for sedimented dust from barns occupied by other farm animals. Pomorska et al. (2009) documented LPS concentration in horse stables between 11 and $110 \mathrm{nmol} \mathrm{LPS} \mathrm{mg}^{-1}$; in poultry houses from 65 to $176 \mathrm{nmol} \mathrm{LPS} \mathrm{mg}^{-1}$ and in sheep sheds between 61 and $226 \mathrm{nmol}$ LPS $\mathrm{mg}^{-1}$. For comparison, the endotoxin concentrations in sedimented dust from various domestic spaces (kitchen, bedroom and living room) is about 1000 times lower ranging between 0.092 and $0.155 \mathrm{nmol} \mathrm{LPS} \mathrm{mg}^{-1}$ (Park et al., 2004).

In the current study, we found that endotoxin concentrations correlated with the number of bacteria from the family Enterobacteriaceae $\left(\mathrm{R}^{2}=0.8495\right)$. Thus, this family of gram-negative bacteria are likely to be mainly responsible for endotoxin presence in this environment. Similar correlation between endotoxin and gram-negative rod concentrations was found by Ławniczek-Wałczyk et al. (2013).

It was shown that bacterial endotoxin exposure through inhalation may lead to respiratory tract inflammation and toxic pneumonitis due to non-specific activation of alveolar macrophages, which release inflammatory mediators. Endotoxins can also cause fever, shivering, cough, and influenza-like symptoms (Lawniczek-Wałczyk and Górny, 2010; Degobbi et al., 2011).

However, the role of endotoxins in the farming environment is still unclear. Endotoxins might act as a coallergen facilitating sensitization to other allergens or they may increase the severity of allergies (Michel et al., 1996; Ormstad et al., 2003). Moreover, some data suggest that the inflammation caused by inhaled endotoxins may decrease the risk of atopic sensitisation amongst children, and can lead to lung cancer amongst workers exposed to organic dust (Rylander, 2002).

\section{Secondary Metabolites}

One-hundred-and-thirteen chemical compounds were detected in sedimented dust sampled on the cattle farm. The most dominant amongst them were metabolites characteristic of the genera Fusarium and Penicillium. Among the less abundant compounds those produced by moulds from the genera Aspergillus, Alternaria and other mould types were identified (Table 7). Interestingly, metabolites of bacterial origin and from lichens as well as phytoestrogens and antibiotics were also detected (Table 7).

The types and concentrations of secondary mould metabolites varied depending on which barn the sedimented dust originated from. Barns 1 and 5 had the lowest number of mould compounds (53 and 54, respectively), while Barns 2 and 4 had the highest (62 and 64, respectively). Mould metabolites that were present at high concentrations in all samples comprised siccanol (724-1560 $\mathrm{ng} \mathrm{g}^{-1}$ ), culmorin (126.5-569 $\mathrm{ng} \mathrm{g}^{-1}$ ), tenuazonic acid (435-540 $\left.\mathrm{ng} \mathrm{g}^{-1}\right)$, altersetin (38.5-457 $\left.\mathrm{ng} \mathrm{g}^{-1}\right)$, flavoglaucin (69.5-1030 $\left.\mathrm{ng} \mathrm{g}^{-1}\right)$, cyclopenol (53.2-122 $\left.\mathrm{ng} \mathrm{g}^{-1}\right)$, viridicatol (54.9-367 $\mathrm{ng} \mathrm{g}^{-1}$ ), aurofusarin (118-226 $\left.\mathrm{ng} \mathrm{g}^{-1}\right)$, fusarinolic acid (120-357 $\mathrm{ng} \mathrm{g}^{-1}$ ), enniatin B1 (97.1-195 $\left.\mathrm{ng} \mathrm{g}^{-1}\right)$, enniatin B (65.2-206 $\left.\mathrm{ng} \mathrm{g}^{-1}\right)$, nivalenol (75.8-120 $\left.\mathrm{ng} \mathrm{g}^{-1}\right)$ and deoxynivalenol (104-176 $\mathrm{ng} \mathrm{g}^{-1}$ ) (Table 7).

The large number of metabolites specific to Fusarium mould and their high concentrations point to the potentially poor microbiological quality of vegetal matter used for feeding and bedding, e.g., haylage, silage, concentrated feed or straw and/or humidity or fungal contamination in the livestock building.

Phytoestrogens are one of many secondary metabolites produced by plants (e.g., legumes, soybeans, beans, nuts, cereals, flax seeds, sesame seeds, hops, and others) during photosynthesis (Graham, 1999). It was shown that legumes, commonly used for feeding farm animals, can contain 5$25 \%$ phytoestrogens. Phytoestrogen concentrations in these plants depend on environmental factors such as temperature, humidity, light, the age of the plant, fertiliser quantity and pathogens (Adams, 1995).

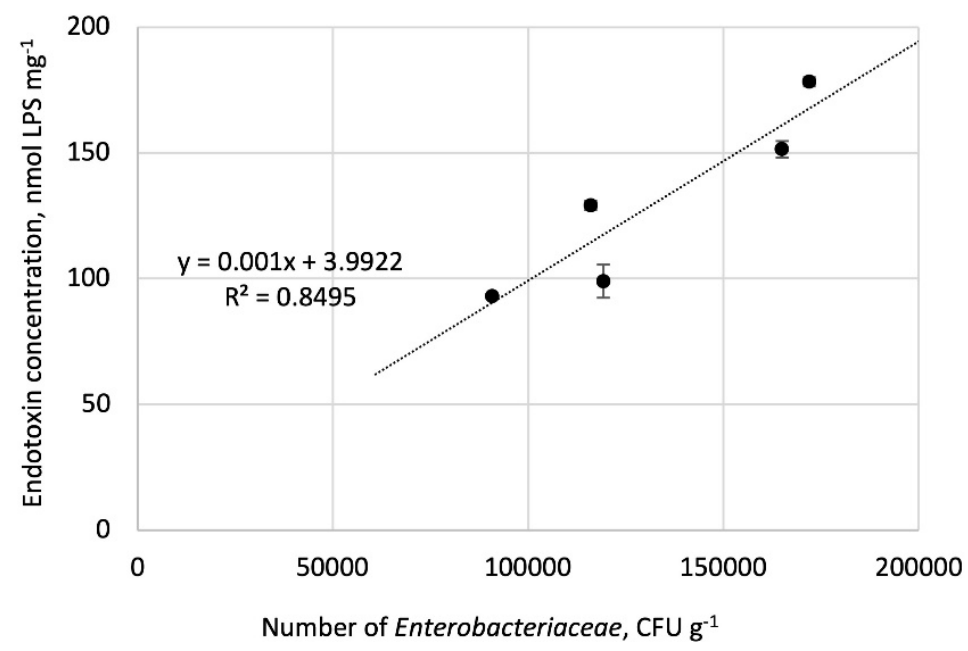

Fig. 4. Endotoxin concentration and correlation between endotoxin concentration and Enterobacteriaceae number in dust samples. 
Table 7. Concentration of secondary metabolites in settled dust samples.

\begin{tabular}{|c|c|c|c|c|c|}
\hline \multirow{2}{*}{ Secondary metabolite } & \multicolumn{5}{|c|}{ Concentration in dust samples $\left(\mathrm{ng} \mathrm{g}^{-1}\right)$} \\
\hline & 1 & 2 & 3 & 4 & 5 \\
\hline \multicolumn{6}{|l|}{ from Alternaria sp. } \\
\hline Alternariol & 28.8 & 19.4 & 26.3 & 16.6 & 23.7 \\
\hline Alternariol methyl ether & 6.07 & 3.75 & 4.10 & 2.13 & 8.32 \\
\hline Altersetin & 59.4 & 57.3 & 73.1 & 39.0 & 457 \\
\hline Infectopyron & 438 & 678 & 501 & 614 & 915 \\
\hline Tentoxin & - & 1.26 & 2.00 & - & 3.38 \\
\hline Tenuazonic acid & 436 & 435 & 530 & 500 & 540 \\
\hline \multicolumn{6}{|l|}{ from Aspergillus sp. } \\
\hline 3-Nitropropionic acid & 11.2 & 10.4 & 15.1 & - & - \\
\hline 8-O-methyl averufin & - & 1.52 & - & - & - \\
\hline Aspulvinone $\mathrm{E}$ & - & - & - & $6,100,000^{*}$ & $51,500,680^{*}$ \\
\hline Averantin & - & 1.43 & - & - & - \\
\hline Averufin & 0.72 & 5.34 & 2.12 & - & - \\
\hline Fumigaclavine & - & 3.45 & - & - & - \\
\hline Fumigaclavine $\mathrm{C}$ & - & 12.1 & - & - & - \\
\hline Fumiquinazoline D & - & 7.53 & - & - & - \\
\hline Methoxysterigmatocystin & 6.34 & 17.2 & 2.03 & 3.67 & - \\
\hline Methyl sulochrin & 1.82 & 6.26 & 2.99 & 3.17 & - \\
\hline Secosterigmatocystin & - & 3.43 & - & - & - \\
\hline Sterigmatocystin & 4.88 & 6.30 & 0.56 & 1.32 & 0.36 \\
\hline Sydowinin A & - & - & 42.6 & - & - \\
\hline Versicolorin C & - & 6.9 & - & - & - \\
\hline \multicolumn{6}{|l|}{ from Fusarium sp. } \\
\hline 15-Hydroxyculmorin & - & - & 109 & 175 & 79.8 \\
\hline 5-Hydroxyculmorin & - & - & 187 & - & 138 \\
\hline Antibiotic Y & 41.5 & - & 26.1 & 45.3 & 94.2 \\
\hline Apicidin & 92.2 & 75.6 & 66.2 & 81.8 & - \\
\hline Aurofusarin & 118 & 132 & 142 & 152 & 226 \\
\hline Beauvericin & 86.9 & 70.3 & 58.4 & 78.7 & 35.8 \\
\hline Chrysogin & 17.3 & 14.4 & 15.0 & 11.8 & 12.7 \\
\hline Culmorin & 217 & 272 & 261 & 569 & 126 \\
\hline Deoxynivalenol & 155 & 107 & 114 & 176 & 104 \\
\hline Enniatin A & 1.44 & 1.23 & 0.93 & 0.71 & 2.01 \\
\hline Enniatin A1 & 39.1 & 30.7 & 30.0 & 21.5 & 53.3 \\
\hline Enniatin B & 119 & 84.4 & 107 & 65.3 & 206 \\
\hline Enniatin B1 & 127 & 97.1 & 107 & 70.6 & 195 \\
\hline Enniatin B2 & 10.9 & 8.02 & 8.04 & 6.42 & 17.7 \\
\hline Enniatin B3 & 0.03 & 0.03 & 0.02 & 0.01 & 0.05 \\
\hline Epiequisetin & 2.57 & 2.53 & 3.06 & 4.20 & - \\
\hline Equisetin & 31.9 & 34.1 & 36.8 & 63.2 & 27.5 \\
\hline Fusaric acid & 322 & - & 356 & 414 & - \\
\hline Fusarinolic acid & 287 & 121 & 342 & 357 & 120 \\
\hline Fusapyrone & - & - & - & 12.9 & - \\
\hline Moniliformin & - & - & 7.38 & 8.81 & 21.2 \\
\hline Nivalenol & 119 & 75.8 & 94.2 & 114 & 88.4 \\
\hline Siccanol & 764 & 724 & 1220 & 1560 & 1480 \\
\hline $\mathrm{T}-2$ toxin & - & - & - & - & 2.95 \\
\hline W493 & 125 & 63.7 & 38.6 & 68.9 & 80.5 \\
\hline Zearalenone & 17.1 & 14.0 & 15.3 & 18.0 & - \\
\hline Zearalenone sulphate & 625,080 & - & 313,440 & - & - \\
\hline \multicolumn{6}{|l|}{ from Penicillium sp. } \\
\hline 7-Hydroxypestalotin & - & 55.6 & - & 41.2 & - \\
\hline Agroclavine & - & 0.46 & - & - & - \\
\hline Andrastin A & - & - & - & 22.6 & - \\
\hline Aurantiamine A & - & - & - & 29.0 & 5.64 \\
\hline
\end{tabular}


Table 7. (continued).

\begin{tabular}{|c|c|c|c|c|c|}
\hline \multirow{2}{*}{ Secondary metabolite } & \multicolumn{5}{|c|}{ Concentration in dust samples $\left(\mathrm{ng} \mathrm{g}^{-1}\right)$} \\
\hline & $\overline{1}$ & 2 & 3 & 4 & 5 \\
\hline Barceloneic acid & 56.3 & 106 & 32.3 & 153 & - \\
\hline Citrinin & - & 49.7 & 149 & 113 & 391 \\
\hline Chanoclavine & 1.13 & 2.46 & 1.27 & 3.11 & 0.73 \\
\hline Curvularin & 15.2 & 18.0 & - & 13.8 & - \\
\hline Cycloaspeptide A & 2.31 & 1.39 & 3.48 & 1.64 & - \\
\hline Cyclopenin & 3.07 & 3.87 & - & 15.0 & 1.64 \\
\hline Cyclopenol & 77.9 & 122 & 53.2 & 115.7 & 88 \\
\hline Cyclopeptine & - & - & - & 8.09 & - \\
\hline Dechlorogriseofulvin & - & - & - & 11.6 & - \\
\hline Dihydrocitrinone & - & - & - & 39.4 & 23.8 \\
\hline Flavoglaucin & 124 & 103 & 69.5 & 280 & 1030 \\
\hline Griseofulvin & - & - & - & 32.0 & - \\
\hline Marcfortine A & 1.17 & 0.56 & 0.65 & 1.55 & - \\
\hline Mycophenolic acid & 7.22 & 14.0 & 82.1 & 17.5 & 3.92 \\
\hline Ochratoxin A & - & 3.58 & 4.47 & - & 10.8 \\
\hline$O$-methyl viridicatin & 1.50 & 4.71 & 1.48 & 7.50 & 3.35 \\
\hline Pestalotin & 5.63 & 33.3 & 4.97 & 23.8 & - \\
\hline Questiomycin A & 9.67 & 36.8 & 7.63 & 37.4 & - \\
\hline Quinolactacin A & 1.57 & 2.05 & 0.95 & 1.84 & 0.56 \\
\hline Roquefortine C & 4.41 & - & 2.80 & 19.6 & - \\
\hline Rugulovasine A & - & 14.7 & 14.4 & - & - \\
\hline Secalonic acid D & 6.87 & 6.67 & 6.34 & 7.47 & 7.45 \\
\hline Verrucofortine & - & - & 0.63 & - & - \\
\hline Viridicatin & - & - & - & 14.5 & - \\
\hline Viridicatol & 54.9 & 200 & 94.9 & 367 & 76.9 \\
\hline \multicolumn{6}{|l|}{ from other fungi } \\
\hline Abscisic acid & 105 & 130 & 165 & 207 & 125 \\
\hline Ascochlorin & 3.13 & 4.08 & - & 7.70 & - \\
\hline Bassianolide & 31.2 & 22.2 & 9.34 & 16.6 & 8.40 \\
\hline Monocerin & 3.03 & 8.47 & - & 4.53 & - \\
\hline Rubellin D & 2.99 & 2.87 & - & 2.36 & - \\
\hline \multicolumn{6}{|l|}{ from bacteria } \\
\hline Dinactin & - & 4.52 & - & - & - \\
\hline Monactin & - & 74.6 & - & 1.31 & - \\
\hline Nonactin & 2.32 & 152 & - & 2.19 & - \\
\hline Valinomycin & - & 16.3 & - & - & - \\
\hline \multicolumn{6}{|l|}{ from lichens } \\
\hline Lecanoic acid & 16.9 & 17.1 & 13.2 & 12.4 & 35.7 \\
\hline Usnic acid & 5.27 & - & - & 3.89 & - \\
\hline \multicolumn{6}{|l|}{ phytoestrogens } \\
\hline Biochanin & 96.5 & 73.3 & 1670 & 42.3 & 105 \\
\hline Daidzein & 439 & 733 & 1510 & 394 & 626 \\
\hline Daidzin & 1420 & 487 & 4890 & 585 & 1940 \\
\hline Formonetin & 336 & 236 & 2050 & 218 & 186 \\
\hline Genistein & 377 & 903 & 1440 & 161 & 846 \\
\hline Genistin & 2380 & 1140 & 5350 & 1020 & 3780 \\
\hline Glycitein & 139 & 275 & 253 & 127 & 183 \\
\hline Glycitin & 359 & 270 & 254 & 120 & 607 \\
\hline Ononin & 79.8 & 14.9 & 50.0 & 39.4 & 26.6 \\
\hline \multicolumn{6}{|l|}{ antibiotics } \\
\hline Lincomycin & - & $3,230,000^{*}$ & - & - & - \\
\hline Oxytetracycline & $2250000^{*}$ & $32,100,000^{*}$ & $73,600,000^{*}$ & $147,000,000^{*}$ & $962,000,000^{*}$ \\
\hline $\begin{array}{l}\text { Tetracycline } \\
\text { unspecific }\end{array}$ & - & $404,640^{*}$ & $365,640^{*}$ & $622,200^{*}$ & $255,000^{*}$ \\
\hline Asperphenamate & 5830 & 19,780 & 9600 & 16,400 & 15,300 \\
\hline
\end{tabular}


Table 7. (continued).

\begin{tabular}{llllll}
\hline \multirow{2}{*}{ Secondary metabolite } & \multicolumn{5}{c}{ Concentration in dust samples $\left(\mathrm{ng} \mathrm{g}^{-1}\right)$} \\
\cline { 2 - 6 } & 1 & 2 & 3 & 4 & 5 \\
\hline Brevianamide F & - & - & 23.4 & 27.4 & - \\
cyclo(L-Pro-L-Tyr) & 167 & 276 & 165 & 401 & 40.6 \\
cyclo(L-Pro-L-Val) & 511 & 285 & 397 & 887 & 57.8 \\
Deoxyfusapyrone & - & - & - & 12.0 & - \\
Emodin & 24.0 & 17.8 & 62.0 & 13.3 & 18.8 \\
Endocrocin & - & 548 & 519 & 329 & 263 \\
Isorhodoptilometrin & 4.27 & 6.20 & 6.08 & 3.29 & 1.72 \\
Lotaustralin & 116 & 41.3 & 43.2 & 63.6 & 55.3 \\
$N$-benzoyl-phenylalanine & 1150 & 6120 & 385 & 6010 & 2920 \\
Neoechinulin A & 488 & 982 & 451 & 536 & 372 \\
Rugulusovin & 6.24 & - & 15.0 & - & - \\
Skyrin & 1.15 & - & - & - & 3.02 \\
Tryptophol & - & - & - & - & 100 \\
\hline
\end{tabular}

-: Below LOD. ${ }^{*}$ Number denotes LC-MS peak area (lack of quantitative standard for this compound).

Genistin (1020-5350 $\left.\mathrm{ng} \mathrm{g}^{-1}\right)$ and daidzein (487-4890 $\left.\mathrm{ng} \mathrm{g}^{-1}\right)$ were detected in all sedimented dust samples at high concentrations. Together with glycitin, present in the dust (120-607 $\left.\mathrm{ng} \mathrm{g}^{-1}\right)$, these isoflavones are dominant compounds in soybeans. The presence of two isoflavones that are characteristic of clover, i.e., biochanin (42.3-1670 $\mathrm{ng} \mathrm{g}^{-1}$ ) and formonetin (186-2050 $\mathrm{ng} \mathrm{g}^{-1}$ ), was also confirmed in dust samples from all barns.

Phytoestrogens were found to have negative effects on the fertility and fecundity of grazing sheep and cows being fed with red clover (clover disease; Yildiz, 2005). It was proven that the consumption of phytoestrogens disturbs hormonal balance in the animal body leading to silent heat, progesterone deficiency, embryonic loss and low semen quality (Glover and Assinder, 2006; Piotrowska et al., 2006). In addition, phytoestrogens were shown to stimulate weight gain and increase growth rate in farm animals (Trenkle and Borroughs, 1978). Oestrogen activity of phytoestrogens depends on many factors such as its chemical structure, bioavailability, species of farm animal, target tissue and oestrogen receptor subtypes (ER $\alpha$ or ER $\beta$ ), and metabolites from the fermentation and digestion of the phytoestrogen.

Literature data indicate that high phytoestrogen consumption in humans is linked to a lower rate of breast and prostate cancer, cardiovascular diseases and osteoporosis (Cornwell et al., 2004). This may be due to the anti-oestrogen action of phytoestrogens in humans and/or their antioxidant activity (Adlercreutz et al., 1995; Siow and Mann, 2010).

Currently, there are no studies on the health consequences of phytoestrogen inhalation in both animals and humans.

Oxytetracycline and tetracycline were detected in the sedimented dust on all cattle breeding premises tested, while lincomycin was detected only in Barn 2 where the number of animals kept was the highest.

Tetracycline and oxytetracycline are used in the prevention and treatment of diseases, and to promote growth in animals such as cattle, pigs, sheep, poultry and others (Daghrir and Drogui, 2013). They are used to treat infections of the respiratory tract (pneumonia), urinary tract, soft tissues, and skin. They are used against infections caused by a wide spectrum of bacteria, except that enteric gramnegative Bacilli and Staphylococci commonly develop resistance to these antibiotics. One of the most common uses in cattle is the treatment of bovine respiratory disease (BRD) caused by Pasteurella multocida, Mannheimia haemolytica, and Histophilus somni (formerly Haemophilus somnus) (Michalova et al., 2004; Papich, 2016).

Lincomycin is an antibiotic used for the treatment of staphylococcal, streptococcal, and Bacteroides fragilis infections in both humans and animals (Spížek and Řezanka, 2004).

Both lincomycin and tetracycline are naturally produced by Actinomycetes from the genus Streptomyces (Procópio et al., 2012); however, it is most likely that they originate mostly from the residues of medicines administered to animals. The presence of antibiotics in cattle breeding environments may contribute to the development of drug resistance by pathogenic microorganisms and cause difficulties in cattle treatment.

Much fewer secondary metabolites ( 22 compounds) were detected in the air of the barns compared to the sedimented dust (Table 8). Amongst them, like in the dust, were compounds characteristic of moulds from the genera Fusarium, Aspergillus, Penicillium and Alternaria, in addition to non-specific compounds. The air of Barn 6 (the milking parlour), where there were neither animals nor vegetal matter, had the lowest metabolite number (4 compounds). On the other hand, Barn 2 (21 compounds) and Barn 4 (10 compounds) had the highest number, which corresponded to the high number of metabolites found in the dust from these barns. In all livestock premises, we detected 3-nitropropionic acid (at a concentration of 19.7-27.9 $\mathrm{ng} \mathrm{m}^{-3}$ ), asperglaucide (5.09-172 $\left.\mathrm{ng} \mathrm{m}^{-3}\right)$, asperphenamate $\left(2.55-89.4 \mathrm{ng} \mathrm{m}^{-3}\right)$, cyclo(L-Pro-L-Tyr) (4.87-8.56 $\mathrm{ng} \mathrm{m}^{-3}$ ), cyclo(L-Pro-L-Val) $\left(6.34-57.0 \mathrm{ng} \mathrm{m}^{-3}\right)$ and flavoglaucin (11.4-79.4 $\left.\mathrm{ng} \mathrm{m}^{-3}\right)$. Of these, 3-nitropropionic acid, cyclo(L-Pro-L-Tyr), and cyclo(L-Pro-L-Val) and, in addition, brevianamide $\mathrm{F}$ were also present in the milking parlour (Barn 6) (Table 8).

Mycotoxins are contaminants of commonly used dairy cattle feeds, including maize, wheat and soybeans, and the processed by-products of these crops, such as maize gluten 
Table 8. Concentration of secondary metabolites in the air of tested premises.

\begin{tabular}{|c|c|c|c|c|c|c|}
\hline \multirow{2}{*}{ Secondary metabolite } & \multicolumn{6}{|c|}{ Concentration in the air $\left(\mathrm{ng} \mathrm{m}^{-3}\right)$} \\
\hline & 1 & 2 & 3 & 4 & 5 & 6 \\
\hline \multicolumn{7}{|l|}{ from Alternaria sp. } \\
\hline Alternariol & - & 4.38 & - & - & - & - \\
\hline Infectopyron & - & 105 & - & - & - & - \\
\hline \multicolumn{7}{|l|}{ from Aspergillus sp. } \\
\hline 3-Nitropropionic acid & 27.9 & 24.8 & 21.9 & 19.7 & 25.5 & 29.3 \\
\hline Festuclavine & - & 0.08 & - & - & - & - \\
\hline Methyl sulochrin & - & 2.07 & - & - & - & - \\
\hline Sterigmatocystin & - & 0.07 & - & - & - & - \\
\hline \multicolumn{7}{|l|}{ from Fusarium sp. } \\
\hline Culmorin & - & - & 25.1 & - & - & - \\
\hline Enniatin A1 & - & 0.88 & - & - & - & - \\
\hline Enniatin B & 0.44 & 4.41 & - & 0.95 & - & - \\
\hline Enniatin B1 & 0.28 & 4.15 & - & 0.31 & - & - \\
\hline \multicolumn{7}{|l|}{ from Penicillium sp. } \\
\hline Andrastin A & - & 5.25 & - & - & - & - \\
\hline Aurantine & - & 6.14 & - & - & - & - \\
\hline Flavoglaucin & 11.4 & 79.4 & 24.8 & 20.0 & 47.4 & - \\
\hline $\begin{array}{l}\text { Quinolactacin A } \\
\text { unspecific }\end{array}$ & - & 0.16 & - & - & - & - \\
\hline Asperglaucide & 23.4 & 172 & 5.09 & 21.6 & 5.5 & - \\
\hline Asperphenamate & 21.1 & 89.4 & 5.48 & 28.9 & 2.55 & - \\
\hline Brevianamide $\mathrm{F}$ & 0.69 & 1.97 & - & 1.01 & 2.08 & 1.75 \\
\hline cyclo(L-Pro-L-Tyr) & 5.39 & 7.89 & 8.56 & 4.87 & 7.56 & 10.7 \\
\hline cyclo(L-Pro-L-Val) & 34.8 & 57.0 & 43.5 & 6.34 & 50.9 & 37.4 \\
\hline Emodin & - & 0.50 & - & 0.26 & - & - \\
\hline$N$-benzoyl-phenylalanine & - & 1.01 & - & - & - & - \\
\hline Neoechinulin A & - & 43.1 & - & - & - & - \\
\hline
\end{tabular}

-: Below LOD.

meal, wheat grits and soybean husks. The most frequently identified mycotoxins present in animal feedstuffs are aflatoxin B1, deoxynivalenol, zearalenone, ochratoxin $\mathrm{A}$, and fumonisins B1 and B2 (Placinta et al., 1999; Driehuis et al., 2008). Driehuis et al. (2008) used LC-MS/MS to identify mycotoxins in 140 maize silages, 120 grass silages and 30 wheat silages manufactured in the Netherlands between the years 2002-2004. They detected deoxynivalenol (DON) in $72 \%$ of maize and $10 \%$ of wheat silage at concentrations of 854 and $621 \mathrm{mg} \mathrm{kg}^{-1}$, respectively. Zearalenone (ZEN) was identified in $49 \%$ of maize and $6 \%$ of grass silage at 174 and $93 \mathrm{mg} \mathrm{kg}{ }^{-1}$, respectively (Driehuis et al., 2008). In the current work, DON occurred in all dust samples and ZEN in $4 / 5$ samples.

Mycotoxicosis is an issue in both humans and animals. In cattle it often remains undiagnosed due to a lack of characteristic clinical signs (Obremski et al., 2009).

According to American and Canadian data, DON causes a decrease in (or no) feed intake, decreased lactation and an increase in the number of somatic cells in milk (Charmley et al., 1993; Diaz et al., 2001). ZEN causes lower milk production, decreased appetite, diarrhoea, inflammatory lesions in the intestinal tract and a number of reproductive tract disturbances (irregular periods in oestrus cycle, silent oestrus, foetus death, abortions, placental retention, and uterus and mammary gland, inflammation) (Obremski et al.,
2009). Although ruminants have the ability to biodegrade mycotoxins, thanks to the presence of bacteria and protozoa in the rumen (presystemic degradation), such mechanisms are disrupted in many cases (high doses and/or high number of disparate mycotoxins). As a result, mycotoxins are not neutralised, and often new toxic compounds are formed that are absorbed in the duodenum, which can damage internal organs. DON and ZEN have a similar effect on human health. In addition, in the current study, other secondary metabolites were detected that may negatively impact the health of people employed in a cattle farm. Fumigaclavines and chanoclavines affect the central and peripheral nervous systems, while roquefortine $\mathrm{C}$, rugulovasines, viridicatin and viridicatol can cause neurohumoral and antibiotic activity (Kozlovsky et al., 2013).

Importantly, the effects of mycotoxin ingestion by animals have been the subject of numerous studies, while still little is known about the health consequences of mycotoxin inhalation (Robbins et al., 2000). It is currently believed that mycotoxin inhalation by humans can be up to ten times more toxic compared to skin, alimentary or intraperitoneal exposure, which is probably due to the ease of penetration across alveoli capillary walls (Soroka et al., 2008). However, there is still a lack of data on mycotoxin concentrations in the air in agricultural work environments and epidemiological data on mycotoxin inhalation by agricultural workers. 


\section{Cytotoxicity of Dust}

In vitro tests, using appropriate cell lines, are useful for characterizing the cytotoxicity of complex mixtures present in the air of different environments, such as organic dust from cattle breeding premises. This is the first report demonstrating cytotoxic effect of dust samples from a cattle farm.
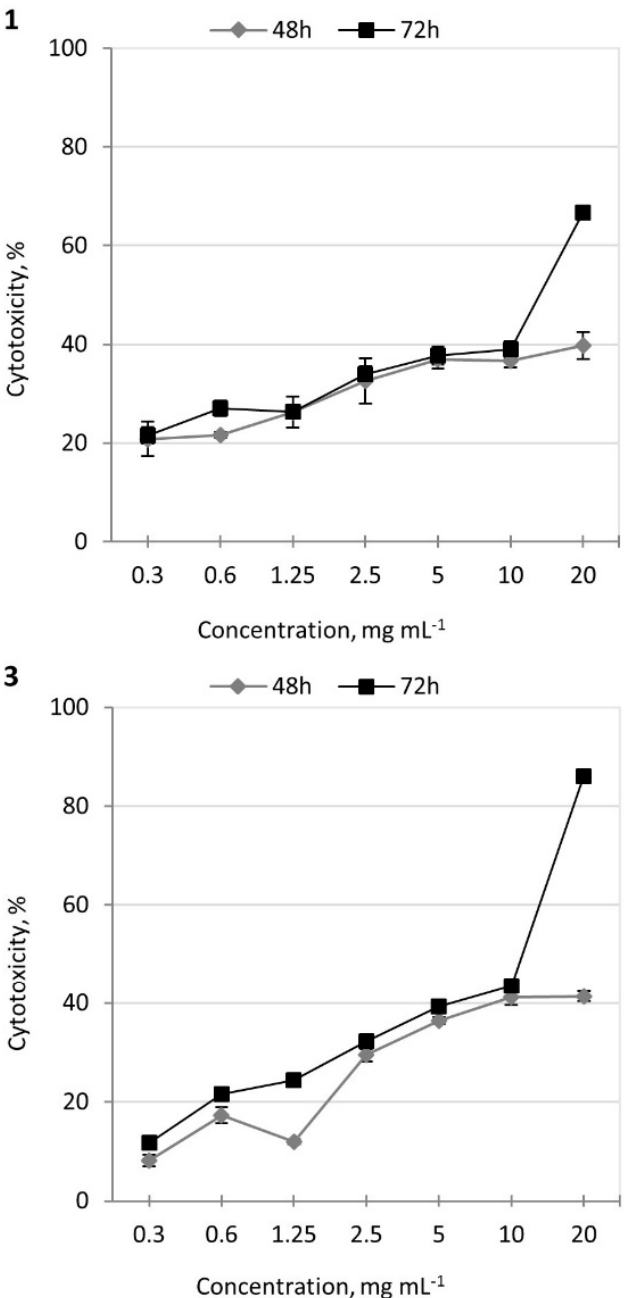

Human epithelial lung cell line, A-549, were exposed to water-soluble fractions of dust samples for 48 and $72 \mathrm{~h}$, with concentrations ranging from 0.3 to $20 \mathrm{mg} \mathrm{mL}^{-1}$. The curves representing cytotoxicity of dust samples are presented in Fig. 5. The $\mathrm{IC}_{50}$ values from the MTT assay are presented in Table 9.
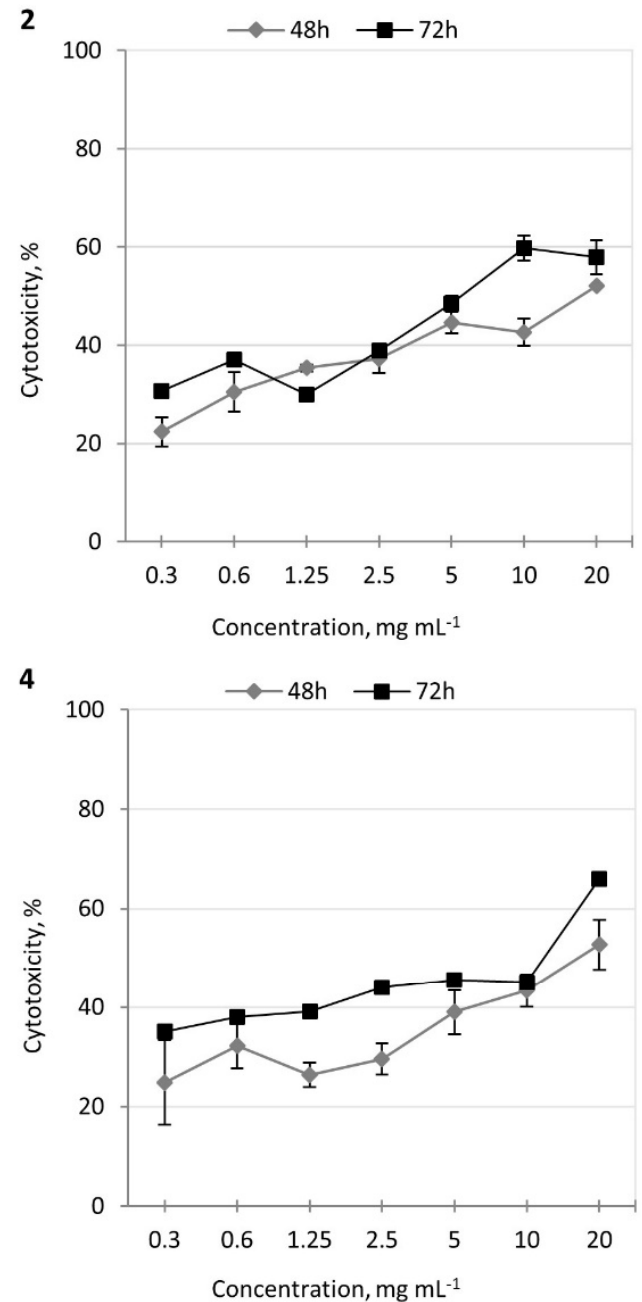

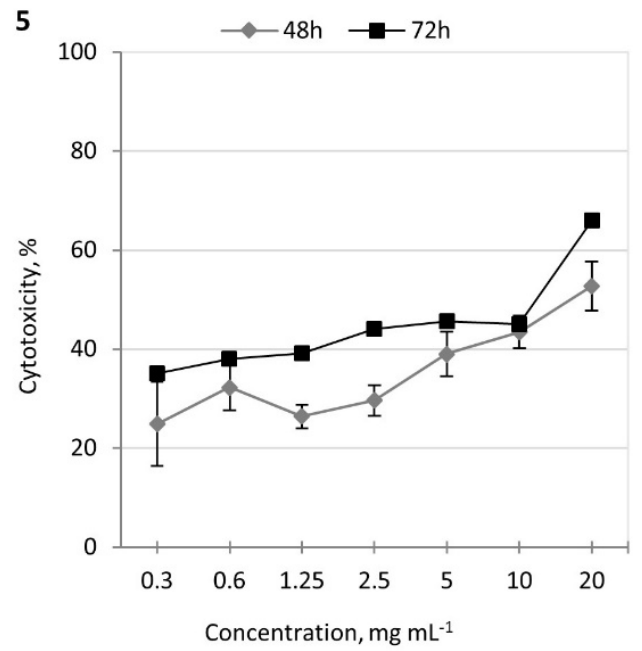

Fig. 5. Cytotoxic activity of water-soluble fractions of dust samples in human lung A-549 cell line, evaluated in MTT assay. Each point represents the mean absorbance values from four repeats $( \pm \mathrm{SD})$. 1-5: Settled dust samples. 
Table 9. Cytotoxicity ( $\mathrm{IC}_{50}$ values) of water-soluble fraction of dust samples from cattle breeding facilities estimated in MTT assay by using the human epithelial lung carcinoma cell line A-549.

\begin{tabular}{llc}
\hline \multirow{2}{*}{ Barn } & \multicolumn{2}{c}{$\mathrm{IC}_{50}\left(\mathrm{mg} \mathrm{mL}^{-1}\right)$} \\
\cline { 2 - 3 } & $48 \mathrm{~h}$ & $72 \mathrm{~h}$ \\
\hline 1 & not detected & 13.99 \\
2 & 17.77 & 5.66 \\
3 & not detected & 11.54 \\
4 & 17.07 & 12.36 \\
5 & not detected & 13.09 \\
\hline
\end{tabular}

Generally, we observed that the cytotoxicity of the fractions increased with concentration. The highest tested concentration $\left(20 \mathrm{mg} \mathrm{mL}^{-1}\right)$ induced the strongest cytotoxic effect, especially after $72 \mathrm{~h}$ exposure. Samples from Barns 2 and 4 exhibited the strongest cytotoxicity, which was always greater than $20 \%$, even at the lowest tested concentrations, amongst all samples. It was only possible to estimate $\mathrm{IC}_{50}$ after $48 \mathrm{~h}$ exposure for samples from these two barns; samples from all other barns required longer exposure times. For instance, the cytotoxicity of samples from Barns 1, 3 and 5 was too low to evaluate $\mathrm{IC}_{50}$ after $48 \mathrm{~h}$. After $72 \mathrm{~h}$, dust from Barn 2 exhibited the strongest cytotoxicity, with an $\mathrm{IC}_{50}$ value of $5.66 \mathrm{mg} \mathrm{mL}^{-1}$ (Table 9). The remaining samples induced comparable results at both exposure times, and after exposure of the cells to $20 \mathrm{mg} \mathrm{mL}^{-1}$ of the sample from Barn 3, the maximal cytotoxicity was about $86 \%$ (after $72 \mathrm{~h}$ ).

The samples from Barn 2 had the highest cytotoxicity. This is in accordance with the concentration of secondary metabolites in the settled dust from this barn, which had the greatest number of fungal compounds. The cytotoxic effect of fungal metabolites on human health is indisputable (Zain, 2011). Barn 2 also had the highest concentration of secondary metabolites in the air, in addition to having antibiotics. Previous work reported the cytotoxic activity of antibiotics on human cell lines, e.g., gingival fibroblasts (FMM1) (Ferreira et al., 2010), hepatoma (C3A), skin fibroblasts (HSF) (Zakrzewska et al., 2014, osteosarcoma (MG63) and cervix carcinoma (HeLa) (Duewelhenke et al., 2006). Antibiotics can disrupt mitochondrial function and induce oxidative stress (Xiao et al., 2019). Oxidative stress to respiratory epithelial cells plays a crucial role in mediating respiratory diseases in farm animals and human workers (McClendon et al., 2015).

\section{CONCLUSIONS}

Cattle breeding premises are diverse work environments where, additionally, many factors, including the animal population, volume of the premises, sanitary conditions, ventilation system and season, can influence the types and risk levels of biological threats. Our research was conducted during winter and early spring, when microorganisms are less likely to survive in the air. Therefore, it is highly probable that greater exposure to individual microbial groups occurs at higher temperatures. Future studies should verify the relationships between the various parameters of cattle breeding premises and of microbiological risks (e.g., the number of microorganisms, the airborne concentrations of the total dust and the levels of endotoxins and mycotoxins) for farms with different characteristics.

Our study found high and very high correlations between the number of microorganisms in the air and that in the dust of the cattle farm, indicating that deposited dust may constitute secondary contamination in such facilities. Therefore, monitoring sanitary conditions and regularly removing sedimented dust may reduce the risk of inhaling particles of microbial origin, including those with allergenic and toxic properties.

High-throughput sequencing revealed a large diversity of microorganisms in both the air and the sedimented dust on the farm, which has not previously been reported in the literature. Of the detected species, those belonging to the genera Corynebacterium, Staphylococcus, Ruminococcus, Aspergillus and Cladosporium, as well as Bacteroides fragilis, were identified as potentially harmful to human and cattle health.

The dust samples contained as many as 113 chemical compounds, including metabolites characteristic of fungal species from the genera Fusarium, Penicillium, Aspergillus and Alternaria; metabolites of bacterial origin; and phytoestrogens and antibiotics in high concentrations, which contributed to the cytotoxicity of the deposited dust to human lung cells. The most cytotoxic sample was collected from the barn with the highest secondary metabolite concentration as well as the worst microbiological contamination (Barn 2). Additionally, the presence of antibiotics (lincomycin, oxytetracycline and tetracycline) has been confirmed in cattle breeding environments, which may account for the development of drug resistance in pathogenic microorganisms.

The concentrations of the airborne dust in the barns did not exceed the threshold limits for workplaces according to national legislation. Therefore, the employees were not legally obligated to wear respiratory protective equipment, e.g., filtering half masks. However, the use of such equipment, with its anti-odour and anti-microbial properties, may enhance the comfort and safety of workers.

Our results demonstrate the complex microbiological risks on cattle farms. We recommend conducting epidemiological studies to determine the effects of exposure to these bioaerosols, endotoxins, mycotoxins, phytoestrogens and antibiotics. Currently, no legal guideline identifies safe inhalation exposure limits or specific health effects for these substances.

\section{ACKNOWLEDGMENTS}

The publication is based on the results of CIOP-PIB statutory project funded in the years 2017-2019 by the Polish Ministry of Science and Higher Education and a research task carried out within the scope of the fifth stage of the National Programme "Improvement of safety and working conditions" partly supported in 2020-2022-within the scope of research and development - by the Ministry of Science and Higher Education/National Centre for Research and Development. The Central Institute for Labour Protection-National Research Institute is the Programme's main coordinator. 


\section{SUPPLEMENTARY MATERIAL}

Supplementary data associated with this article can be found in the online version at http://www.aaqr.org.

\section{REFERENCES}

Adams, N.R. (1995). Detection of the effects of phytoestrogens on sheep and cattle. J. Anim. Sci 73: 1509-1515. https://doi.org/10.2527/1995.7351509x

Adlercreutz, C.H., Goldin, B.R., Gorbach, S.L., Höckerstedt, K.A., Watanabe, S., Hämäläinen, E.K., Markkanen, M.H., Mäkelä, T.H., Wähälä, K.T. and Adlercreutz, T. (1995). Soybean phytoestrogen intake and cancer risk. J. Nutr. 125: 757-770. https://doi.org/10.1093/jn/125.3_Suppl.757S

Bartelink, A.K.M. and van Kregten, E. (1995). Streptococcus suis as a threat to pig-farmers and abattoir workers. Lancet 346: 1770. https://doi.org/10.5555/uri:pii :S014067369592874X

Bennett J.W. and Klich, M. (2003). Mycotoxins. Clin. Microbiol. Rev. 36: 497-516. https://doi.org/10.1128/CM R.16.3.497-516.2003

Berard, K. (2012). The genus Corynebacterium and other medically relevant coryneform-like bacteria. J. Clin. Microbiol. 50: 3152-3158. https://doi.org/10.1128/JCM. 00796-12

Caporaso, J.G., Kuczynski, J., Stombaugh, J., Bittinger, K., Bushman, F.D., Costello, E.K., Fierer, N., Peña, A.G., Goodrich, J.K., Gordon, J.I., Huttley, G.A., Kelley, S.T., Knights, D., Koenig, J.E., Ley, R.E., Lozupone, C.A., McDonald, D., Muegge, B.D., Pirrung, M., Reeder, J., Sevinsky, J.R., Turnbaugh. P.J., Walters, W.A., Widmann, J., Yatsunenko, T., Zaneveld, J. and Knight, R. (2010). QIIME allows analysis of high-throughput community sequencing data. Nat. Methods 7: 335-336. https://doi.org/ 10.1038/nmeth.f.303

Charmley, E., Trenholm, H.L., Thompson, B.K., Vudathala, D., Nicholson, J.W.G., Prelusky, D.B. and Charmley, L.L. (1993). Influence of level of deoxynivalenol in the diet of dairy cows feed intake, milk production and its composition. J. Dairy Sci. 6: 3580-3587. https://doi.org/ 10.3168/jds.S0022-0302(93)77697-3

Chen, S., Wang, Y., Chen, F., Yang, H., Gan, M. and Zheng, S.J. (2007). A highly pathogenic strain of Staphylococcus sciuri caused fatal exudative epidermitis in piglets. PLoS One 2: e147. https://doi.org/10.1371/journal.pone.0000147

Chow, S.K., Bui, U. and Clarridge, J.E. (2015). Corynebacterium bovis eye infections. Emerging Infect. Dis. 21: 1687-1689. https://doi.org/10.3201/eid2109.150520

Cornwell, T., Cohick, W. and Raskin, I. (2004). Dietary phytoestrogens and health. Phytochemistry 65: 9951016. https://doi.org/10.1016/j.phytochem.2004.03.005

Corrao, C.R.N., Mazzotta, A., La Torre, G. and De Giustim, M. (2012). Biological risk and occupational health. Ind. Health 50: 326-337. https://doi.org/10.2486/indhealth.M S1324

Daghrir, R. and Drogui, P. (2013). Tetracycline antibiotics in the environment: A review. Environ. Chem. Lett. 11: 209-227. https://doi.org/10.1007/s10311-013-0404-8
Dave, P., Mahendra, R. and Pal, M. (2015). Etiologic significance of Aspergillus terreus in primary cutaneous mycosis of an agricultural worker. Mol. Microbiol. Res. 5: 1-4. https://doi.org/10.5376/mmr.2015.05.0002

Degobbi, C., Saldiva, P.H.N. and Rogers, C. (2011). Endotoxins as modifier of particulate matter toxicity: A review of the literature. Aerobiologia 27: 97-105. https://doi.org/10.1007/s10453-010-9179-6

Desnos-Ollivier, M., Ragon, M., Robert, V., Raoux, D., Gantier, J.C. and Dromer, F. (2008). Debaryomyces hansenii (Candida famata), a rare human fungal pathogen often misidentified as Pichia guilliermondii (Candida guilliermondii). J. Clin. Microbiol. 46: 3237-3242. https://doi.org/10.1128/JCM.01451-08

Diaz, D.E., Hagler, W.M., Hopkins, B.A., Patton, R.A., Brownie, C. and Whitlow, L.W. (2001). The effect of inclusion of a clay type sequestering agent on milk production of dairy cattle consuming mycotoxin contaminated feeds. J. Dairy Sci. 84: 1554.

Driehuis, F., Spanjer, M.C., Scholten, J.M. and Te Giffel, M.C. (2008). Occurrence of mycotoxins in maize, grass and wheat silage for dairy cattle in the Netherlands. Food Addit. Contam. 1: 41-50. https://doi.org/10.1080/193932 10802236927

Duewelhenke, N., Krut, O. and Eysel, P. (2006). Influence on mitochondria and cytotoxicity of different antibiotics administered in high concentrations on primary human osteoblasts and cell lines. Antimicrob. Agents Chemother. 51: 54-63. https://doi.org/10.1128/AAC.00729-05

Dungan, R.S., Leytem, A.B., Verwey, S.A. and Bjorneberg, D.L. (2010). Assessment of bioaerosols at a concentrated dairy operation. Aerobiologia 26: 171-184. https://doi.org/ 10.1007/s10453-010-9154-2

Dutkiewicz, J., Pomorski, Z.J.H., Sitkowska, J., KrysinskaTraczyk, E., Skorska, C., Prazmo, Z., Cholewa, G. and Wojtowicz, H. (1994). Airborne microorganisms and endotoxin in animal houses. Grana 33: 85-90. https://doi.org/10.1080/00173139409427837

Dutkiewicz, J., Cisak, E., Sroka, J., Wójcik-Fatla, A. and Zając, V. (2011). Biological agents as occupational hazards selected issues. Ann. Agric. Environ. Med. 18: 286-293.

Edgar, R.C. (2010). Search and clustering orders of magnitude faster than BLAST. Bioinformatics 26: 2460 2461. https://doi.org/10.1093/bioinformatics/btq461

Ejlertsen, T., G ahrn-Hansen, B., Sogaard, P., Heltberg, O. and Frederiksen, W. (1996). Pasteurella aerogenes isolated from ulcers or wounds in humans with occupational exposure to pig: A report of 7 Danish cases. Scand. J. Infect. Dis. 28: 567-570. https://doi.org/10.3109/003655 49609037962

EN 13098:2001 Workplace atmospheres. Guidelines for measurement of airborne micro-organisms and endotoxin.

European Commission (2002). 2002/657/EC: Commission Decision of 12 August 2002 implementing Council Directive 96/23/EC concerning the performance of analytical methods and the interpretation of results. Official Journal of the European Communities 2002, L 221: 8-29.

European Parliament, Council of the European Union 
(2000). Directive 2000/54/EC of the European Parliament and of the Council of 18 September 2000 on the Protection of Workers from Risks Related to Exposure to Biological Agents at Work. https://eur-lex.europa.eu/legalcontent/EN/ALL/?uri=CELEX\%3A32000L0054

Ferreira, M.B., Myiagi, S., Nogales, C.G, Campos, M.S. and Lage-Marques, J.L. (2010). Time- and concentrationdependent cytotoxicity of antibiotics used in endodontic therapy. J. Appl. Oral. Sci. 18: 259-263. https://doi.org/1 $0.1590 / \mathrm{S} 1678-77572010000300011$

Food and Agriculture Organization of the United Nations (FAO) (2012). Animal Production and Health: Sources of Meat. Third. Guide for the Care and Use of Agricultural Animals Used in Agricultural Research and Teaching. http://www.fao.org/ag/againfo/themes/en/meat/backgr_s ources.html

GESTIS (2018) International occupational exposure limit values for chemical agents. http://limitvalue.ifa.dguv.de/

Glover, A. and Assinder, S.J. (2006). Acute exposure of adult male rats to dietary phytoestrogens reduces fecundity and alters epididymal steroid hormone receptor expression. J. Endocrinol. 189: 565-573. https://doi.org/ 10.1677/joe. 1.06709

Graham, T. (1999). Biosynthesis and distribution of phytoestrogens and their roles in plant defense, signal transduction, and cell-to-cell signaling. J. Med. Food. 2: 93-97. https://doi.org/10.1089/jmf.1999.2.93

Gutarowska, B., Szulc, J., Nowak, A., Otlewska, A., Okrasa, M., Jachowicz, A. and Majchrzycka, K. (2018). Dust at various workplaces - microbiological and toxicological threats. Int. J. Environ. Res. Public Health 15: 877. https://doi.org/10.3390/ijerph15050877

Hameed, A.A. and Khodr, M.I. (2001). Suspended particulates and bioaerosols emitted from an agricultural non-point source. J. Environ. Monit. 3: 206-209. https://doi.org/10.1039/B007159P

Hinkle, D.E., Wiersma, W. and Jurs, S.G. (2003). Applied statistics for the behavioral sciences 5th ed. Houghton Mifflin, Boston.

Kõljalg, U., Nilsson, R.H., Abarenkov, K., Tedersoo, L., Taylor, A.F.S., Bahram, M., Bates, S.T., Bruns, T.D., Bengtsson-Palme, J., Callaghan, T.M., Douglas, B., Drenkhan, T., Eberhardt, U., Dueñas, M., Grebenc, T., Griffith, G.W., Hartmann, M., Kirk, P.M., Kohout, P., Larsson, E., ... Larsson, K.H. (2013). Towards a unified paradigm for sequence-based identification of Fungi. Mol. Ecol. 22: 5271-5277. https://doi.org/10.1111/mec.12481

Kozlovsky, A.G., Zhelifonova, V.P. and Antipova, T.V. (2013). Biologically active metabolites of Penicillium fungi. J. Org. Biomol. Chem. 1: 11-21.

Kwon-Chung, K.J. and Sugui, J.A. (2013). Aspergillus fumigatus-What makes the species a ubiquitous human fungal pathogen? PLoS Pathog. 9: e1003743. https://doi.org/10.1371/journal.ppat.1003743

Lacey, J. and Crook B. (1988). Review: Fungal and actinomycete spores as pollutants of the workplace and occupational allergens. Ann. Occup. Hyg. 32: 515-533. https://doi.org/10.1093/annhyg/32.4.515

Lange, J.L., Thorne, P.S. and Kullman, G.J. (1997).
Determinants of culturable bioaerosol concentrations in dairy barns. Ann. Agric. Environ. Med. 4: 187-194.

Larsson, K., Malmberg, P., Eklund, A., Belin, L. and Blaschke, E. (1988). Exposure to microorganisms, airway inflammatory changes and immune reactions in asymptomatic dairy farmers. Int. Arch. Allergy. Immunol. 87: 127-133. https://doi.org/10.1159/000234662

Ławniczek-Wałczyk, A. and Górny, R.L. (2010). Endotoxins and $\beta$-glucans as markers of microbiological contamination - characteristics, detection, and environmental exposure. Ann. Agric. Environ. Med. 17: 193-208.

Ławniczek-Walczyk, A., Górny, R.L., Golofit-Szymczak, M., Niesler, A. and Wlazlo, A. (2013). Occupational exposure to airborne microorganisms, endotoxins and $\beta$ glucans in poultry houses at different stages of the production cycle. Ann Agric Environ Med. 20: 259-268.

Lecours, P.B., Veillette, M., Marsolais, D. and Duchaine, C. (2012). Characterization of bioaerosols from dairy barns: reconstructing the puzzle of occupational respiratory diseases by using molecular approaches. Appl. Environ. Microbiol. 78: 3242-3248. https://doi.org/10.1128/AEM. 07661-11

Lee, S.A., Adhikari, A., Grinshpun, S.A., McKay, R., Shukla, R. and Reponen, T. (2006). Personal exposure to airborne dust and microorganisms in agricultural environments. $J$. Occup. Environ. Hyg. 3: 118-130. https://doi.org/10.1080 /15459620500524607

Malachová, A., Sulyok, M., Beltrán, E., Berthiller, F. and Krska, R. (2014). Optimization and validation of a quantitative liquid chromatography-tandem mass spectrometric method covering 295 bacterial and fungal metabolites including all regulated mycotoxins in four model food matrices. J. Chromatogr. A 1362: 145-156. https://doi.org/10.1016/j.chroma.2014.08.037

McClendon, C.J., Gerald, C.L. and Waterman, J.T. (2015). Farm animal models of organic dust exposure and toxicity: insights and implications for respiratory health. Curr. Opin. Allergy Clin. Immunol. 15: 137-144. https://doi.org/10.1097/ACI.0000000000000143

McCormick, A., Loeffler, J. and Ebel F. (2010). Aspergillus fumigatus: Contours of an opportunistic human pathogen. Cell. Microbiol. 12: 1535-1543. https://doi.org/10.1111/j. 1462-5822.2010.01517.x

Michalova, E., Novotna, P. and Schlegelova, J. (2004). Tetracyclines in veterinary medicine and bacterial resistance to them. Vet. Med. 49: 79-100.

Michel, O., Kips, J., Duchateau, J., Vertongen, F., Robert, L., Collet, H., Pauwels, R. and Sergysels, R. (1996). Severity of asthma is related to endotoxin in house dust. Am. J. Respir. Crit. Care Med. 154: 1641-1646. https://doi.org/10.1164/ajrccm.154.6.8970348

Milanowski, J., Dutkiewicz, J., Potoczna, H., Kuś, L. and Urbanowicz, B. (1998). Allergic alveolitis among agricultural workers in eastern Poland: A study of twenty cases. Ann. Argic. Environ. Med. 5: 31-43.

Obremski, K., Zielonka, Ł., Gajęcka, M., Jakimiuk, E. and Gajęcki, M. (2009). Mycotoxins - dairy cattle breeding problem. A case report. Bull. Vet. Inst. Pulawy 53: 221-224. OECD (2018). Guidelines for the Testing of Chemicals, 
Section 4. Test No. 442D: In vitro skin sensitisation. https://doi.org/10.1787/9789264229822-en

Ormstad, H., Groeng, E.C., Duffort, O. and Lovik, M. (2003). The effect of endotoxin on the production of IgE, IgG1 and IgG2a antibodies against the cat allergen Fel d 1 in mice. Toxicology 188: 309-318. https://doi.org/10.1016/ s0300-483x(03)00078-7

Papich, M.G. (2016). Saunders Handbook of Veterinary Drugs, Small and Large Animal, 4th Edition, Elsevier Inc., St. Louis, Missouri, USA.

Park, J.H., Szponar, B., Larsson, L., Gold, D.R. and Milton, D.K. (2004). Characterization of lipopolysaccharides present in settled house dust. Appl. Environ. Microbiol. 70: 262267. https://doi.org/10.1128/aem.70.1.262-267.2004

Piotrowska, K.K., Wocławek-Potocka, I., Bah, M.M., Piskula, M.K., Pilawski, W., Bober, A. and Skarzynski, D.J. (2006). Phytoestrogens and their metabolites inhibit the sensitivity of the bovine corpus luteum to luteotropic factors. J. Reprod. Dev. 52: 33-41. https://doi.org/10.126 2/jrd.17054

Placinta, C.M., D’Mello, J.P.F. and Macdonald, A.M.C. (1999). A review of worldwide contamination of cereal grains and animal feed with Fusarium mycotoxins. Anim. Feed Sci. Technol. 78: 21-37. https://doi.org/10.1016/S0 377-8401(98)00278-8

Pomorska, D., Larsson, L., Skórska, C., Sitkowska, J. and Dutkiewicz, J. (2009). Levels of bacterial endotoxin in the samples of settled dust collected in animal houses. Bull. Vet. Inst. Pulawy. 53: 37-41.

Procópio, R.E., Silva, I.R., Martins, M.K., Azevedo, J.L. and Araújo, J.M. (2012). Antibiotics produced by Streptomyces. Braz. J. Infect. Dis. 16: 466-471. https://doi.org/10.1016/ j.bjid.2012.08.014

Riegel, P., Heller, R., Prevost, G., Jehl, F. and Monteil, H. (1997). Corynebacterium durum sp. nov., from human clinical specimens. Int. J. Syst. Bacteriol. 47: 1107-1111. https://doi.org/10.1099/00207713-47-4-1107

Rim, K.T. and Lim, C.H. (2014). Biologically hazardous agents at work and efforts to protect workers' health: A review of recent reports. Saf. Health Work 5: 43-52. https://doi.org/10.1016/j.shaw.2014.03.006

Robbins, C.A., Swenson, L.J., Nealley, M.L., Gots, R.E. and Kelman, B.J. (2000). Health effects of mycotoxins in indoor air: A critical review. Appl. Occup. Environ. Hyg. 15: 773-784. https://doi.org/10.1080/10473220050129419

Rylander, R. (2002). Review: Endotoxin in the environment - exposure and effects. J. Endotoxin Res. 8: 241-252. https://doi.org/10.1177/09680519020080040101

Rylander, R. and Peterson, Y. (1994). Causative agents for organic dust related disease. Am. J. Ind. Med. 25: 1-146.

Sahin, I., Kaya, D., Parlak, A.H., Oksuz, S. and Behcet, M. (2005). Dermatophytoses in forestry workers and farmers. Mycoses 48: 260-264. https://doi.org/10.1111/j.14390507.2005.01135.x

Sandoval-Denis, M., Gené, J., Sutton, D.A., Wiederhold, N.P., Cano-Lira, J.F. and Guarro, J. (2016). New species of Cladosporium associated with human and animal infections. Persoonia 36: 281-298. https://doi.org/10.376 7/003158516X691951
Schaal, K.P. and Lee, H.J. (1992). Actinomycete infections in humans - A review. Gene 115: 201-211. https://doi.org/10.1016/0378-1119(92)90560-c

Schmidt, P., Bálint, M., Greshake, B., Bandow, C., Römbke, J. and Schmitt, I. (2013). Illumina metabarcoding of a soil fungal community. Soil Biol. Biochem. 65: 128-132. https://doi.org/10.1016/j.soilbio.2013.05.014

Sebastian, A. and Larsson, L. (2003). Characterization of the microbial community in indoor environments: A chemicalanalytical approach. Appl. Environ. Microbiol. 69: 3103-3109. https://doi.org/10.1128/aem.69.6.31033109.2003

Seedorf, J., Hartung, J., Schröder, M., Linkert, K.H., Phillips, V.R., Holden, M.R., Sneath, R.W., Short, J.L., White, R.P., Pedersen, S. Takai, H., Johnsen, J.O., Metz, J.H.M., Groot Koerkamp, P.W.G., Uenk, G.H. and Wathes, C.M. (1998). Concentrations and emissions of airborne endotoxins and microorganisms in livestock buildings in Northern Europe. J. Agr. Eng. Res. 70: 97109. https://doi.org/10.1006/jaer.1997.0281

Siow, R.C.M. and Mann, G.E. (2010). Dietary isoflavones and vascular protection: Activation of cellular antioxidant defenses by SERMs or hormesis? Mol. Aspects Med. 31: 468-477. https://doi.org/10.1016/j.mam.2010.09.003

Skóra, J., Matusiak, K., Wojewódzki, P., Nowak, A., Sulyok, M., Ligocka, A., Okrasa, M., Hermann, J., and Gutarowska, B. (2016). Evaluation of microbiological and chemical contaminants in poultry farms. Int. J. Environ. Res. Public Health 13: 192. https://doi.org/10.33 90/ijerph13020192

Soroka, P.M., Cyprowski, M. and Szadkowska-Stańczyk, I. (2008). Occupational exposure to mycotoxins in various branches of industry. Med. Pr. 59: 333-345.

Spížek, J. and Řezanka, T. (2004). Lincomycin, clindamycin and their applications. Appl. Microbiol. Biotechnol. 64: 455-464. https://doi.org/10.1007/s00253-003-1545-7

Sulyok, M., Berthiller, F., Krska, R. and Schuhmacher, R. (2006). Development and validation of a liquid chromatography/ tandem mass spectrometric method for the determination of 39 mycotoxins in wheat and maize. Rapid Commun. Mass Spectrom. 20: 2649-2659. https://doi.org/10.1002/rcm.2640

Sulyok, M., Krska, R. and Schuhmacher, R. (2007). A liquid chromatography/tandem mass spectrometric multimycotoxin method for the quantification of 87 analytes and its application to semi-quantitative screening of moldy food samples. Anal. Bioanal. Chem. 389: 15051523. https://doi.org/10.1007/s00216-007-1542-2

Titecat, M., Wallet, F., Vieillard, M.H., Courcol, R.J. and Loïez, C. (2014). Ruminococcus gnavus: An unusual pathogen in septic arthritis. Anaerobe 30: 159-160. https://doi.org/10.1016/j.anaerobe.2014.10.001

Trenkle, A. and Borroughs, W. (1978). Physiological effects of estrogens in animal feeds with emphasis on growth of ruminants. Nutrition and drug interrelations. Academic Press, New York, pp. 577-611.

Wexler, H. (2007). Bacteroides: The good, the bad, and the nitty-gritty. Clin. Microbiol Rev. 20: 593-621. https://doi.org/10.1128/CMR.00008-07 
White, T., Bruns, T., Lee, S. and Taylor, J. (1990). Amplification and direct sequencing of fungal ribosomal RNA genes for phylogenetics. In PCR Protocols: A guide to methods and applications. Innis, M., Gelfand, D., Shinsky, J. and White, T. (Eds.), Academic Press, San Diego, pp. 315-322.

Wong, S.C.Y., Poon, R.W.S., Chen, J.H.K., Tse, H., Lo, J. Y.C., Ng, T.K. Au, J.C.K., Tse, C.W.S., Cheung, I.Y.Y., Yuk, M.T., Luk, W.K. and Yuen, K.Y. (2017). Corynebacterium kroppenstedtii is an emerging cause of mastitis especially in patients with psychiatric illness on antipsychotic medication. Open Forum Infect Dis. 4: ofx096. https://doi.org/10.1093/ofid/ofx096

Xiao, Y., Xiong, T., Meng, X., Yu, D., Xiao, Z. and Song, L. (2019). Different influences on mitochondrial function, oxidative stress and cytotoxicity of antibiotics on primary human neuron and cell lines. J. Biochem. Mol. Toxicol.
33: e22277. https://doi.org/10.1002/jbt.22277

Yildiz, F. (2005). Phytoestrogens in functional foods. Taylor \& Francis. Ltd. pp. 3-5: 210-211.

Zain, M.E. (2011). Impact of mycotoxins on humans and animals. J. Saudi. Chem. Soc. 15: 129-144. https://doi.org/ 10.1016/j.jscs.2010.06.006

Zakrzewska, K.E., Samluk, A., Pluta, K.D. and Pijanowska, D.G. (2014). Evaluation of the effects of antibiotics on cytotoxicity of EGFP and DsRed2 fluorescent proteins used for stable cell labelling. Acta Biochim. Pol. 61: 809813. https://doi.org/10.18388/abp.2014 1850

Received for review, December 18, 2019 Revised, March 8, 2020 Accepted, April 9, 2020 